IZA DP No. 8962

Immigration, Regional Conditions, and Crime:

Evidence from an Allocation Policy in Germany

Marc Piopiunik

Jens Ruhose

March 2015 


\title{
Immigration, Regional Conditions, and Crime: Evidence from an Allocation Policy in Germany
}

\author{
Marc Piopiunik \\ Ifo Institute, University of Munich \\ and CESifo \\ Jens Ruhose \\ Ifo Institute, University of Munich \\ and IZA
}

Discussion Paper No. 8962

March 2015

IZA
P.O. Box 7240
53072 Bonn
Germany

Phone: +49-228-3894-0

Fax: +49-228-3894-180

E-mail: iza@iza.org

\begin{abstract}
Any opinions expressed here are those of the author(s) and not those of IZA. Research published in this series may include views on policy, but the institute itself takes no institutional policy positions. The IZA research network is committed to the IZA Guiding Principles of Research Integrity.

The Institute for the Study of Labor (IZA) in Bonn is a local and virtual international research center and a place of communication between science, politics and business. IZA is an independent nonprofit organization supported by Deutsche Post Foundation. The center is associated with the University of Bonn and offers a stimulating research environment through its international network, workshops and conferences, data service, project support, research visits and doctoral program. IZA engages in (i) original and internationally competitive research in all fields of labor economics, (ii) development of policy concepts, and (iii) dissemination of research results and concepts to the interested public.
\end{abstract}

IZA Discussion Papers often represent preliminary work and are circulated to encourage discussion. Citation of such a paper should account for its provisional character. A revised version may be available directly from the author. 
IZA Discussion Paper No. 8962

March 2015

\section{ABSTRACT}

\section{Immigration, Regional Conditions, and Crime: Evidence from an Allocation Policy in Germany}

After the collapse of the Soviet Union, more than 3 million people with German ancestors immigrated to Germany under a special law granting immediate citizenship. Exploiting the exogenous allocation of ethnic German immigrants by German authorities across regions upon arrival, we find that immigration significantly increases crime. The crime impact of immigration depends strongly on local labor market conditions, with strong impacts in regions with high unemployment. Similarly, we find substantially stronger effects in regions with high preexisting crime levels or large shares of foreigners.

JEL Classification: F22, J15, K42, R10

Keywords: immigration, crime, allocation policy

Corresponding author:

Jens Ruhose

Ifo Institute

Poschingerstr. 5

81679 Munich

Germany

E-mail: ruhose@ifo.de

\footnotetext{
* We are grateful to George J. Borjas, Oliver Falck, Albrecht Glitz, Eric A. Hanushek, Ludger Woessmann, and participants at the Ifo Institute in Munich, ESPE in Braga, EEA in Toulouse, and EALE in Ljubljiana for helpful comments and discussion. This project was funded through the Leibniz Competition (SAW-2012-ifo-3).
} 


\section{Introduction}

Criminal behavior of immigrants is a huge concern in many countries. In Europe, the majority of native residents is worried about immigrants increasing crime, whereas only a minority is worried about immigrants taking jobs away (Fitzgerald et al., 2012). The widespread concern about crime might therefore play a greater role in shaping immigration policies than do labor market concerns (Card et al., 2012). While the literature on the labor market effects of immigration is huge (see Friedberg and Hunt, 1995; Borjas, 1999; Card, 2009, for overviews), the crime effects of immigration has been explored much less.

Existing research on the crime impact of immigration tends to find zero or small effects. Bianchi et al. (2012) exploit the increase in the immigrant population in Italy in the 1990s that was mainly driven by the collapse of the Soviet Union and the Balkan Wars, finding strong effects on robberies, but a negligible effect on total crime. Bell et al. (2013) study the impact on crime of two different immigration waves to the United Kingdom: migrant laborers from eight European countries that joined the EU in 2004 and asylum seekers. The authors find an effect only for asylum seekers, and only on property crime. For the United States, Butcher and Piehl $(1998,2007)$ find no significant relationship between immigration and crime at the state level, and Chalfin (2013), using data at the metropolitan area level, finds no evidence that Mexican immigrants increase crime. Spenkuch (2013) uses county data and finds effects on property crime, but not on violent crime.

We contribute to this literature by investigating the crime impact of a particular group of low-educated immigrants to Germany who were allocated across regions by German authorities upon arrival. We find that these immigrants increased crime substantially. In particular, crime effects are much stronger in regions with adverse conditions such as high unemployment and high preexisting crime levels.

The group of immigrants we focus on in this study are ethnic Germans who lived in Eastern Europe and the former Soviet Union before migrating to Germany after the fall of the Berlin Wall. Between 1988 and 2005, more than 3 million ethnic Germans immigrated, increasing Germany's population by about 5\%. Immediately after immigrating, ethnic German immigrants were granted German citizenship, were allowed to work, and were eligible to social security assistance (like German natives). Despite legally being Germans, ethnic German immigrants have considerably lower education levels, worse labor market outcomes, and lower incomes than native Germans (see Table A-2). Based on these characteristics, however, ethnic German immigrants are similar to other immigrants in Germany.

Upon arrival in Germany, ethnic German immigrants are allocated across counties by state authorities. We exploit this allocation policy to identify the causal effect of 
ethnic German immigrants on crime. ${ }^{1}$ The number of migrants allocated to a particular county is set by policymakers and depends largely on the number of residents, economic conditions, and other factors such as housing capacities. While German authorities determine the number of ethnic German immigrants allocated to a particular county, each immigrant can express preferences to live in the county where her relatives are already living. If the county quota is not already exhausted, authorities try to meet these family preferences. ${ }^{2}$ Therefore, the specific county of residence where a newly arriving ethnic German immigrant is allocated to, depends mostly on family ties. Noncompliance with the residence allocation, which is binding for three years, is severely sanctioned with the withdrawal of all social benefits, implying that self-selection into regions is highly restricted. Since the residence of family members is the main allocation criterion and labor market skills do not play any role (Glitz, 2012, p. 180), the allocation is likely exogenous with respect to regional crime and labor market conditions. This allocation, therefore, provides a unique quasi-experimental setting for studying the effects of immigration on crime. Furthermore, as the allocation policy has likely led to similar skill and age distributions of ethnic German immigrants across regions, we are able to assess the importance of regional conditions for the crime impact. ${ }^{3}$

We combine annual county-specific inflows of ethnic German immigrants with annual county-specific crime rates. We merge information on labor market conditions and demographics of the counties to investigate whether regional conditions influence the impact of immigration on crime. We focus on West Germany (excluding Berlin) from 1996 until 2005, the period during which newly arriving ethnic German immigrants were allocated across regions by German authorities. Thus, our sample includes 185 counties over a 10-year period.

The results indicate that ethnic German immigrants increase crime rates substantially. An immigrant inflow of one ethnic German per 1,000 inhabitants increases total crime by about $0.9 \%$, which amounts to an elasticity of approximately 0.5 . Effects vary by type of crime, with strong impacts on burglary, property damage, and battery, but no effect on street-related types of crime. We also find evidence that regional labor market conditions are crucial. While immigration has no effect on crime in regions with low unemployment,

\footnotetext{
${ }^{1}$ Glitz (2012) exploits the same allocation policy to estimate the impact of immigrants on skill-specific employment rates and wages of natives, finding a displacement but no wage effect. Other studies exploiting allocation policies (typically involving refugees) include, for example, Edin et al. (2003); Damm (2009); Damm and Dustmann (2014).

${ }^{2}$ Note that although the majority of individual residence choices depended on family ties, the variation in the size of immigrant flows across regions is not based on networks as in the shift-share approach (Card, 2001). Indeed, in our case, the regional distribution of resident immigrants cannot be used as an instrument for the allocation of new immigrants across regions.

${ }^{3}$ Hjalmarsson and Lindquist (2012) find that children of criminal fathers are much more likely of having a criminal conviction than those with noncriminal fathers. We argue in Section 4 that intergenerational correlation in crime is likely not an issue in our setting.
} 
crime effects are strong in regions with high unemployment. Furthermore, we find much stronger impacts in regions with high preexisting crime levels.

In their economic theory of crime, Becker (1968) and Ehrlich (1973) argue that the propensity for committing a crime decreases with legitimate earnings opportunities, the probability of being convicted, and the cost of conviction. The cost of conviction is particularly interesting since it might differ between immigration groups. Because citizenship reduces the cost of conviction by eliminating the threat of deportation (Spenkuch, 2013), this might be one explanation why the crime effects we find are larger than those found in other studies, given that ethnic Germans are granted German citizenship immediately upon arrival. ${ }^{4}$

We contribute to the literature by providing the first assessment of the importance of local labor market conditions for the crime impact of immigration. Existing studies either investigate the impact of local labor market conditions on crime in general (without focusing on immigrants) or study the impact of immigrants on crime without considering the potentially important role of local labor market conditions. Assessing the importance of local labor market conditions is feasible in this setting since the allocation policy led to similar skill and age distributions of newly arriving ethnic German immigrants across counties. In contrast, immigrants studied elsewhere could always choose their region of residence without any restrictions (with the exception of refugees). Furthermore, we estimate short-run effects of immigration on crime by exploiting annual immigration inflows. Based on changes in immigrant stocks over time, existing studies, in contrast, estimate medium- or long-run effects. If immigrants are more likely to commit crimes in the first years after arrival, for example, because integration into the new society takes some time, then we are able to detect crime effects that have been missed in previous studies.

The remainder of the paper proceeds as follows. Section 2 provides some background of ethnic German immigrants and describes the allocation process. Section 3 presents the data, and Section 4 lays out the empirical model. Section 5 reports the main results, robustness checks, and effect heterogeneities with respect to regional conditions. Section 6 concludes.

\section{Ethnic German Immigrants and the Allocation Policy}

Ethnic German immigrants are descendants of German colonists who had migrated to Russia and other East European countries in the 18th and 19th century (Bade, 1990). During World War II, many ethnic Germans - considered potential collaborators with

\footnotetext{
${ }^{4}$ In the United States, for example, 816,000 criminal immigrants were removed from the country between 1998 and 2007 because of a criminal charge or conviction (Camarota and Vaughan, 2009, p. 2).
} 
the Nazi regime - were forced to leave their original settlements and to move eastward to Siberia, Kazakhstan, and to regions in Middle Asia where they lived in special settlements.

During the Cold War, only few ethnic Germans were allowed to emigrate (see Figure 1). Toward the end of the communist regime, restrictions were alleviated, leading to a massive emigration wave driven by bad economic and political conditions in the Soviet Union (Bade and Oltmer, 2003). Since the end of the 1980s, more than 3 million ethnic German immigrants have arrived in Germany. There was a heavy inflow of ethnic German immigrants in the late 1980s and early 1990s, with a peak of 397,000 individuals in 1990. Due to this huge immigration, a yearly quota of about 225,000 individuals was introduced in 1993 and further reduced to about 100,000 individuals per year in 2000 . Due to these quotas, and because the stock of German descendants in the former Soviet Union was becoming smaller, the number of immigrating ethnic Germans decreased over time. $^{5}$ The collapse of the Soviet Union changed the composition of countries where ethnic German immigrants were coming from. Between 1950 and 1987, only about $7 \%$ of ethnic German immigrants came from countries of the former Soviet Union. In contrast, since the mid-1990s, almost all ethnic German immigrants have come from former Soviet Union countries, especially Kazakhstan, Kirgisistan, Usbekistan, Ukraine, and the Russian Federation (see Figure 1).

The immigration of ethnic Germans was administered centrally by the Federal Office of Administration (Bundesverwaltungsamt). First, all ethnic Germans had to apply for a visa at the German embassy in their country of residence. To be recognized as an ethnic German, an applicant had to fulfill all requirements of the Federal Refugees Act. Legally, individuals are considered members of German minorities if they meet the following three requirements (Peters, 2003). They (1) have to be descendants of at least one parent or grandparent with German nationality; (2) must have declared "confession to German ethnicity" before leaving the settlement area, typically by possessing the German nationality, sending their children to a German school, or through being a member in a German association; and (3) are able to conduct a simple conversation in German. Due to assimilation pressures in their settlement areas, ethnic German immigrants had rather low German language proficiency, however. Therefore, language requirements were kept at a low level. To maintain the unity of the family, ethnic Germans were allowed to immigrate together with their spouses and all offsprings, given that the marriage had existed for at least three years. Ethnic Germans and all relatives migrating with them were granted German nationality immediately upon arrival. ${ }^{6}$

All arriving ethnic German immigrants had to pass through a central admission center. If ethnic German immigrants did not have a job or another source of income- which was

\footnotetext{
${ }^{5}$ Ethnic German immigrants do not include East Germans who moved to West Germany after the fall of the Berlin Wall.

${ }^{6}$ In the remainder of the paper, the term ethnic German immigrants includes both persons of own German descent as well as their spouses and children.
} 
the case for the vast majority (see below) - they were allocated to one of the 16 German states according to predefined quotas (Königsteiner Schlüssel). These quotas, which have been adjusted every year, are based on the tax revenues (weight of two thirds) and the population size (one third) of each state.

Based on the Place of Residence Allocation Act (Wohnortzuweisungsgesetz), which has been established in 1989 due to the large inflow, most states subsequently allocated ethnic German immigrants across counties. The goal of the allocation across counties was a socially acceptable integration of these immigrants. Because ethnic German immigrants preferred to live close to their relatives, and because noncompliance with the assignment did not have any consequences at the beginning of the 1990s, many ethnic Germans left their assigned county and moved to other counties. This led to a strong inflow of ethnic German immigrants into some regions (Swiaczny and Mammey, 2001). Because municipalities were responsible for the housing of ethnic German immigrants and for the payment of social assistance, this implied great financial burdens for municipalities with high shares of ethnic Germans. Furthermore, high concentrations of ethnic German immigrants increased the necessity of integration measures and lowered the acceptance among native Germans (Haug and Sauer, 2006). Seven counties which were particularly hit by massive inflows of ethnic German immigrants therefore signed the so-called "Gifhorn Declaration for the Integration of Ethnic German immigrants" in March 1995, demanding a more solidary distribution of the burdens between states and municipalities (Niedersächsische Landeszentrale für Politische Bildung, 2002, p. 10). ${ }^{7}$ This declaration led to an important amendment to the Place of Residence Allocation Act that mandated that ethnic German immigrants were bound to their assigned county during the first three years after immigration. Most importantly, the amendment introduced severe sanctions: Ethnic German immigrants would lose all social benefits and any type of public assistance in case of noncompliance with the allocation decision. Only ethnic Germans who could prove both a job and housing in their preferred county were exempt from this rule. However, survey evidence (presented below) indicates that only a minority of arriving ethnic German immigrants was able to freely choose their county of residence. Most West German states implemented the new law in March 1996, while Hesse adopted the law in January 2002, and two states (Bavaria and Rhineland-Palatine) did not adopt it at all. ${ }^{8}$

The allocation of ethnic German immigrants across counties was not handled uniformly by the states. Typically, the number of ethnic German immigrants allocated to the counties was based on quotas that partly depended on the size of the resident population.

\footnotetext{
${ }^{7}$ These counties were Wolfsburg, Salzgitter, Gifhorn, Nienburg/Weser, Cloppenburg, Emsland, and Osnabrück. Dropping these counties from the analysis does not affect the results.

${ }^{8}$ The amendment which introduced sanctions for leaving the assigned county was indeed effective. For example, the counties of the Gifhorn Declaration received only few ethnic German immigrants after the law was adapted in March 1996 (Wenzel, 1999). Glitz (2012, p. 181) furthermore notes that the perception at the Ministry of the Interior and the Association of German Cities and Towns was that the sanctions were effective and ensured high compliance with the initial allocation decision.
} 
The allocation also depended on other factors, such as intake capacities or the size of the county area in some states (e.g. North Rhine-Westphalia). Some states adjusted their quotas to changes in the counties' population size, while other states did not. Table A-1 in the Appendix indicates that ethnic Germans were indeed allocated according to these official criteria. Counties with larger populations and counties with higher GDP per capita (although statistically insignificant) received more ethnic Germans. Because previous inflows reflect time-persistent county characteristics that are not captured by the other covariates, the compound inflow in the previous three years is a predictor of the current inflow. 9

The actual county of residence of new ethnic German immigrants was largely determined by family ties. While German authorities determined the number of ethnic German immigrants allocated to a particular county in a given year, each new immigrant could express her preferences to live in the county were her relatives were already living. If the quota for the desired county was not already exhausted, the authorities tried to meet the immigrant's preferences. The Ministry of the Interior estimates that the presence of family members was the decisive factor for the allocation decision in about $90 \%$ of all cases. The presence of health and care facilities and the infrastructure for single parents were additional factors. Most importantly, however, the skill level or the previous crime history of ethnic German immigrants did not play any role in the allocation process (Glitz, 2012, p. 180).

Even though official data are lacking ${ }^{10}$, there is strong evidence that the vast majority of ethnic German immigrants stayed in their assigned county of residence during the period of retention, that is, during the first three years after immigration. First, the vast majority of ethnic German immigrants depended on social welfare, thus rendering departure from the assigned county very costly. In a survey among 1,554 ethnic German immigrants, only $11 \%$ reported that they did not receive any type of social benefit or state assistance during the first three years after arrival (Haug and Sauer, 2007, p. 101). Furthermore, only $36 \%$ of ethnic Germans worked at some point during the first three years after arrival (Haug and Sauer, 2007, p. 120). Second, ethnic German immigrants were likely to comply with the assignment because they depended on state-financed housing. After arriving in Germany, about $80 \%$ of ethnic German immigrants lived in temporary residential homes or admission centers (Seifert, 1996), staying on average about two years in the temporary

\footnotetext{
${ }^{9}$ One potential issue - frequently discussed in the migration literature (Borjas, 1994) — is that residents move to other counties in response to immigrant inflows. In our case, potential outflows of residents would be problematic if individuals with high (low) crime propensities would move, thus leading to an underestimation (overestimation) of the true crime effect. In line with findings that Germany has a rather inflexible labor market (Pischke and Velling 1997), Glitz (2012) has shown that there is no systematic outflow of residents in response to the inflow of ethnic Germans.

${ }^{10}$ Because ethnic German immigrants cannot be identified in the registration offices of the municipalities due to their German citizenship, the number of ethnic German immigrants residing in a given county is unknown.
} 
residential homes (Mammey, 1999). Adolescent ethnic German immigrants are also very likely (about 51\%) to live in residential establishments or in social housing, compared to $10 \%$ of native Germans (Dietz, 1999, Table 12).

Concerning socioeconomic characteristics, ethnic German immigrants have worse outcomes than native Germans. One reason is that the share of ethnic German immigrants of own German descent was only $47.7 \%$ in 1996 and declined even further to only $21.5 \%$ in 2005 (Haug and Sauer, 2006, p. 417). Accordingly, the German language proficiency of ethnic Germans is rather low. Another factor is that ethnic Germans had to assimilate in their home countries, thereby losing German language skills. Even among ethnic German immigrants who immigrated in the early 1990s - when the majority was of own German descent - self-assessed German language proficiency at the end of the 1990s was not better than the language proficiency of other immigrants who immigrated in the same years, and was even worse than the language proficiency of second-generation immigrants in Germany (Haug, 2005). ${ }^{11}$

Young ethnic German immigrants also tend to have low education. Administrative school data from the largest German state, North Rhine-Westphalia, for the school year 1996/1997 show that children from ethnic Germans are highly overrepresented in the least academic secondary school track (Hauptschule) (Dietz, 1999, Table 9). The occupational composition of newly arriving ethnic German immigrants also indicates a rather loweducated immigrant group. Ethnic German immigrants are highly overrepresented in low-skill occupations such as farmers, laborers, transport workers, operatives, and craft workers (see Glitz 2012, p. 188f.).

Statistics based on the German Mircocensus 2008, the first large-scale survey that allows identifying ethnic German immigrants unambiguously, shows that ethnic German immigrants have much worse socioeconomic outcomes than native Germans, but similar outcomes than other immigrants in Germany (see Table A-2 in the Appendix). Both ethnic German immigrants and other immigrants are heavily overrepresented in the two lowest education categories (Panel B). While ethnic German immigrants have somewhat better employment outcomes than other immigrants, both groups have substantially worse outcomes than native Germans, in particular much higher unemployment rates and higher incidences of temporary employment (Panel C). Ethnic German immigrants and other immigrants have lower incomes than native Germans (Panel D). Finally, ethnic German immigrants and other immigrants are much more likely to receive social assistance (Hartz IV) and unemployment benefits (ALG I) than natives.

In sum, although ethnic German immigrants are of German descent, they have much poorer socioeconomic characteristics and worse employment outcomes than native

\footnotetext{
${ }^{11}$ The low German language proficiency might partly be due to the fact that only few ethnic Germans had native Germans as friends (Dietz, 1999). One reason for the lack of friendships might be the negative attitude of native Germans toward ethnic Germans, which was sometimes more negative than toward foreigners (Fertig and Schmidt, 2001).
} 
Germans. Employment outcomes of ethnic German immigrants and other immigrant groups in Germany, however, are rather similar.

\section{Data}

We have collected administrative data on reported crime at the county level (NUTS-3) from the State Offices of Criminal Investigation (Landeskriminalämter) for the years 19972002 and from the Federal Criminal Police Office (Bundeskriminalamt) for the years 20032006. We were able to collect data on total crime and several important subcategories: battery, drug offense, property damage, burglary, and street crime. ${ }^{12}$

Table A-3 in the Appendix reports the states used in the analysis along with county-byyear observation numbers for the different crime categories. We include all West German states that allocated ethnic German immigrants across counties. ${ }^{13}$ The first year in our sample is 1996 because the allocation was not binding before, and the last year is 2005 since ethnic German inflows into Germany were rather small afterwards (see Figure 1). ${ }^{14}$

Table 1 reports summary statistics of the county-by-year data. Panel A reports the crime rates for total crime and the five subcategories. Crime rates are defined as the number of crimes reported to the police per 100,000 inhabitants:

$$
\text { Crime }_{\text {rate }}=\frac{\text { reported } \text { crimes }_{t} \times 100,000}{\text { population }_{t-1}}
$$

The average total crime rate in our sample is 6,883 crimes per 100,000 inhabitants. Compared to the mean, the standard deviation of 2,661 crimes is large, which is mainly driven by large differences between counties. After taking out permanent differences between counties and yearly fluctuations within states by regressing the crime rate on county and year-by-state fixed effects, the variations in crime rates decrease substantially (see Adj. SD).

\footnotetext{
${ }^{12}$ Total crime contains any type of crime reported to the police. Battery includes, among others, bodily harm with fatal consequences, grievous and serious bodily harm, and bodily injury caused by negligence. Drug offense contains all crimes associated with general violations of the narcotics law, drugs trafficking, and illegal importation of drugs. Property damage covers all crimes that involve destroying, damaging or making useless another person's property. Burglary contains all crimes that include housebreaking for committing theft. Street crime is a mixed category that includes various street-related crimes, for example, theft of, in, and out of cars and robberies. Crime categories can be reviewed in the List of Crimes (Straftatenkatalog) from the Federal Criminal Police Office.

${ }^{13}$ The two states Bavaria and Rhineland-Palatinate did not allocate ethnic German immigrants across counties. We focus on West Germany (excluding Berlin) because crime data at the county level are not available for East German states for the years 1997-2002.

${ }^{14}$ Hamburg starts only in 1999 due to missing information on ethnic German immigrant inflows, and Hesse starts only in 2003 because the allocation across counties started only in 2002. Observation numbers vary by crime category due to missing data. Furthermore, crime data for North Rhine-Westphalia were only provided at the level of police administration areas. While in most cases police administration areas are identical with the borders of counties, we had to aggregate 14 counties (8.3\%) into 6 police administration areas.
} 
The relative importance of each crime category can be expressed by the number of crimes in the respective category as a percentage of total crime. The largest crime category is street crime covering $27.1 \%$ of all reported crimes. The second biggest category is property damage with $11.0 \%$, followed by battery $(7.2 \%)$, drug offense $(4.2 \%)$, and burglary (1.9\%). Taken together, these five crime categories account for $51.4 \%$ of all reported crimes.

Annual county-level data on the inflows of ethnic German immigrants come from two sources. Inflow data from 1996 to 2001 is taken from Glitz (2012) which originally come from the admission centers in each state. Inflow data from 2002 to 2006 come from the Bundesarbeitsgemeinschaft Ev. Jugendsozialarbeit e.V., Jugendmigrationsdienste which is a church initiative that takes care of underprivileged youths. This initiative collected the data directly from the state Ministries of the Interior. We checked the comparability of the two different data sources by comparing the data for the overlapping years (1998-2001), finding a very high degree of consistency.

Summary statistics of ethnic German immigrant inflows across counties are reported in Panel B of Table 1. The average yearly inflow between 1996 and 2005 was 293 ethnic German immigrants per county, with a minimum of 0 and a maximum of 2,393 immigrants. There is substantial variation across counties, with a standard deviation of 270 ethnic German immigrants. Taking out time-invariant county differences and year-by-state fluctuations, the adjusted standard deviation (Adj. SD) is 93 ethnic German immigrants.

The main explanatory variable of interest is the ethnic German inflow rate. The inflow rate is defined as the number of ethnic German immigrants assigned to a particular county in year $t$ divided by the population of that county at the end of year $t-1:{ }^{15}$

$$
\text { Ethnic German inflow rate } \text { re }_{t}=\frac{\text { number of allocated ethnic German immigrants }}{\text { population }_{t-1}}
$$

Across all counties and all years, the average inflow rate was about one ethnic German immigrant per 1,000 inhabitants. Over the entire sample period (1996-2005), the average inflow rate was 12 ethnic German immigrants per 1,000 inhabitants, that is, more than one percent of Germany's population. This inflow rate implies that the average county received 3,151 ethnic German immigrants between 1996 and 2005. Because quotas were not only based on population size, inflow rates do vary across counties. For example, combining all years in our sample period, the inflow rate varies between 2 ethnic German immigrants per 1,000 inhabitants and 22 ethnic German immigrants per 1,000 inhabitants.

\footnotetext{
${ }^{15}$ Alternatively defining the inflow rate as the number of assigned ethnic Germans divided by the county's population plus the number of assigned ethnic Germans yields very similar results. Using the absolute ethnic German inflow, that is, the number of assigned ethnic Germans, leads to very similar results (not reported).
} 
Summary statistics of additional county characteristics are reported in Panel $\mathrm{C}$ of Table 1, including demographic information such as population, share of foreigners, and share of young male adults aged 15 to 39. Unemployment rate and GDP per capita reflect the regional labor market conditions. Finally, we use crime-specific clear-up rates as proxies for the probability of being arrested (see Panel D of Table 1), with the clear-up rate being defined as the number of crimes that are cleared times 100 and divided by the number of reported crimes.

\section{Empirical Model}

To investigate the effect of immigration on crime, we estimate the following model:

$$
\begin{gathered}
\text { In }{\text { crime } \text { rate }_{i s t}}=\alpha+\beta \text { ethnic German inflow rate } \text { ist }-1+ \\
\mathbf{X}_{\mathbf{i s t}-\mathbf{1}}{ }^{\prime} \gamma+\mu_{i}+\left(\mu_{t} \times \mu_{s}\right)+\epsilon_{i s t}
\end{gathered}
$$

where the logarithm of the crime rate in county $i$ in state $s$ in year $t$ is regressed on the ethnic German inflow rate of the previous year. We control for county fixed effects $\left(\mu_{i}\right)$ to eliminate any time-invariant determinants of crime across counties. Furthermore, we include year-by-state fixed effects $\left(\mu_{t} \times \mu_{s}\right)$ to net out crime trends that are common to all counties within a state. ${ }^{16} \mathbf{X}_{\mathbf{i s t}-\mathbf{1}}$ includes lagged time-varying county characteristics such as demographics and economic conditions.

It is a well-known problem in the crime literature that reported crimes underestimate the true (but unobserved) number of committed crimes (e.g., Bianchi et al., 2012). This may lead to biased estimates if the extent of underreporting is correlated with the determinants of crime. For this reason, crime studies use the logarithm of the crime rate and include region and year fixed effects in the regression model (Levitt, 1996; Gould et al., 2002; Öster and Agell, 2007; Fougère et al., 2009; Bianchi et al., 2012). Using the logarithm of the crime rate and including these fixed effects eliminates any measurement error that is constant within regions over time and any measurement error that is constant across regions in any time period. This arguably eliminates various important sources of underreporting, such as cultural differences across regions or changing crime-awareness over time (e.g. transported via national media).

\footnotetext{
${ }^{16}$ Note that this model is more demanding, but also more realistic, than a model that includes only year fixed effects. There are three reasons for including year-by-state fixed effects. First, each state decides how to allocate ethnic German immigrants across its counties. Therefore, changes in the state-specific allocation rule would affect all counties within the same state, but would not affect counties in other states. Second, states, not the federal level, have the authority over police issues. For example, each state decides about hiring new police officers and how to allocate police officers across counties. Third, states differ in the proximity to neighboring countries which might lead to different crime developments over time. Figure 2 presents the crime trends for six states in our sample, showing that state-specific crime rates develop differently over time. These differing crime trends are taken into account by including year-by-state fixed effects.
} 
We cluster standard errors at the level of the included fixed effects, that is, we assume the following error structure: $\epsilon_{i s t}=\theta_{i}+\left(\theta_{t} \times \theta_{s}\right)+\eta_{i s t}$. We allow the error term to be correlated within counties over time $\left(\theta_{i}\right)$ and within year-by-state cells across counties $\left(\theta_{t} \times \theta_{s}\right)$. Clustering standard errors at the year-by-state level is motivated by the fact that states are responsible for allocating both ethnic German immigrants and police forces across counties. We use two-way clustered standard errors to account for the two dimensions of correlated standard errors. ${ }^{17}$

We control for several lagged county characteristics $\left(\mathbf{X}_{\mathbf{i s t}-\mathbf{1}}\right)$ that might affect crime rates. Demographic characteristics include the logarithm of the population ${ }^{18}$, the share of foreigners, and the share of young male adults (aged 15-39) since this population group is particularly likely to commit crimes (Freeman, 1999). We also include the logarithm of GDP per capita and the unemployment rate to control for labor market opportunities. Finally, we include the clear-up rate for the respective crime category as a proxy for the expected costs of crime (see Ehrlich, 1996). Note that all county characteristics are also lagged by one year since the inflow of ethnic German immigrants in year $t-1$ might affect these characteristics in year $t$, thus rendering county characteristics in year $t$ bad controls (Angrist and Pischke, 2009). ${ }^{19}$

Given that the allocation of ethnic German immigrants was binding for three years, we are able to identify the short-run impact of immigration on crime. Because we exploit annual inflow data - and because the stock of ethnic German immigrants is not availablewe cannot identify medium- to long-run effects.

By relating the crime rate in year $t$ to the migrant inflow in the previous year $(t-1)$, the empirical model is set up to reflect this short-run perspective. Using the one-year lag of the inflow ensures that we do not erroneously attribute crimes committed at the beginning of year $t$ to ethnic German immigrants who arrived at the end of year $t$. Depending on the exact date of arrival during year $t-1$, the model captures any crime committed during the first or during the first two years after arrival. If immigrants have particularly poor labor market outcomes in the first years after arrival, for example, due to occupational downgrading, crime impacts might be stronger in the short run than in the long run.

The identification of a causal effect on crime depends on the exogeneity of the allocation with respect to transitory regional crime conditions. The exogeneity requirement is likely satisfied because the main allocation criterion, as pointed out by Glitz (2012, p. 193), was the proximity of family members and because labor market skills did not play a role in the allocation process. Glitz provides evidence that the allocation

\footnotetext{
${ }^{17}$ See Cameron et al. (2011) and Thompson (2011) for theoretical derivations of the two-way clustering method and Acemoglu and Pischke (2003) for an application of two-way clustering. We use the Stata command IVREG 2 for computing two-way clustered standard errors.

${ }^{18}$ Since the model includes county fixed effects, population size also captures population density, which is one determinant of criminal behavior (Glaeser and Sacerdote, 1999).

${ }^{19}$ Results do not change if we use contemporaneous county characteristics instead.
} 
across states was exogenous with respect to individual characteristics "as suggested by the overwhelming importance of family ties for the allocation decision." He finds that the age distributions of ethnic German immigrants across the West German states are very similar (with standard deviations being much smaller than the corresponding standard deviations of the overall population), which should be the case if immigrants were exogenously allocated with respect to individual characteristics. Glitz argues that this finding also indicates that the allocation within states was also exogenous since the allocation across counties followed similar administrative processes and decision criteria as the previous allocation to states. In sum, because both skills and age - two important determinants of crime - were no factors in the allocation process of ethnic German immigrants, the skill and age distributions of newly arriving ethnic German immigrants should be similar across counties. ${ }^{20}$

One potential issue is that children of criminal fathers are much more likely of being convicted than children with noncriminal fathers, with parents' background explaining the vast majority of this relationship (Hjalmarsson and Lindquist, 2012). For intergenerational correlation in crime to invalidate our identification strategy, the family members already living in Germany who are less criminal must have self-selected into regions with low unemployment or low crime rates. To the extent that county-specific labor market and crime conditions are persistent, we solve this issue by including county fixed effects in the model. The only remaining worry is that individuals with low crime propensities moved to regions with good conditions during our 9-year-sample period before their family members immigrated. In addition, the intergenerational correlation in crime between newly arriving ethnic German immigrants and their family members is likely to be zero or small in our case since these families were typically split up a long time ago (Glitz, 2012, p. 183), and therefore raised in very different environments (unlike the parents and their offsprings in other studies).

\section{Results}

We first present results on the impact of immigration on total crime and on the various subcategories (Section 5.1). We then provide evidence that the allocation of ethnic German immigrants was not affected by regional crime rates and robustness checks (Section 5.2). Finally, we assess whether crime effects depend on regional labor market conditions, preexisting crime levels, or on the share of foreigners (Section 5.3).

\footnotetext{
${ }^{20} \mathrm{Glitz}(2012)$ correctly notes that this assumption may not hold if the skills between immigrants and their relatives are correlated. However, because family members were typically separated a long time ago and attended different education systems, the correlation in skills is likely to be small.
} 


\subsection{Main Results}

Table 2 presents the impact of immigration on total crime. Controlling for county and year-by-state fixed effects, we find that larger inflows of immigrants raises total crime the following year (Column 1). Adding population size and GDP per capita-the two main factors in determining the allocating of ethnic German immigrants across counties-does not change the coefficient (Column 2). Given that county fixed effects are included, it is not surprising that the coefficients on population size and GDP per capita are close to zero. Adding unemployment rate, share of foreigners, share of young men, and clear-up rate decreases the coefficient of interest only slightly (Column 3). Again, the coefficients on these control variables are close to zero.

To interpret the coefficient on the inflow rate causally, one has to assume that the inflow rate is exogenous to local crime conditions, conditional on all covariates. In contrast, the effect of immigration on crime is not estimated consistently if there are factors that affect both the inflow rate and the crime rate (e.g. labor market conditions that are not perfectly captured by the included controls). The coefficient would be underestimated, for example, if states allocated more ethnic German immigrants to counties with falling crime rates. ${ }^{21}$ Therefore, we add county-specific linear time trends to estimate the effect of immigration on crime that results from deviations of linear time trends. Adding linear time trends reduces the coefficient of interest only slightly, but inflates the standard error by more than 50\% (Column 4). However, controlling for region-specific time trends is problematic because time trends likely pick up part of the treatment effects, and not just preexisting trends (Wolfers, 2006). This is especially problematic in this setting because our sample does not include any pre-treatment periods, that is, years without any inflow of ethnic German immigrants. For this reason, we consider the specification in Column (3) as the baseline model.

How large is the effect of immigration on crime? For expositional purposes, we compute the effect size for a doubling of the average ethnic German inflow rate, that is, an increase in the inflow by one immigrant per 1,000 inhabitants (or 293 immigrants per county). ${ }^{22}$ Multiplying the increase in the inflow rate $(0.001)$ with the estimated coefficient yields an increase in total crime by $0.8756 \%$, or about $0.9 \%$.

To compare this semi-elasticity with the crime elasticities reported in other studies, we need the stock of ethnic German immigrants in Germany. The Microcensus 2008 is the first large-scale administrative survey that allows identifying ethnic German immigrants (and their offsprings) unambiguously based on their self-reported status. In the eight states used in the analysis, the share of ethnic German immigrants (including offsprings) in the total population is $5.4 \%$, or 54 ethnic German immigrants per 1,000 residents.

\footnotetext{
${ }^{21}$ This seems, however, not to be the case as inflow rates are completely unrelated to the lagged crime rate (see Table 4 ).

${ }^{22}$ Note that this increase is somewhat larger than the standard deviation of the inflow rate $(0.0007)$.
} 
Therefore, an increase in the inflow of one ethnic German immigrant per 1,000 residents increases the stock of ethnic German immigrants by about $1.85 \%(=1 / 54)$. This implies an elasticity for total crime of $0.49(=0.9 \% / 1.85 \%)$. Importantly, this elasticity is an upper bound of the true elasticity since the stock of ethnic German immigrants was somewhat lower during the analysis period (1996-2005). Assuming, for example, that the stock of ethnic German immigrants was on average one percentage point lower (that is, $4.4 \%$ )-consistent with the compound inflow rate of $1 \%$ during our analysis period-the crime elasticity would be 0.40 .

The crime elasticity is considerably larger than those reported in previous studies. Bianchi et al. (2012) estimate a very low elasticity for total crime of about 0.03 for Italy, finding a statistically significant effect only for robberies (of elasticity 1). Bell et al. (2013) find an elasticity for total crime of about 0.16 for asylum seekers in England.

There are two potential explanations why we find stronger effects. The first explanation concerns a crucial difference between the immigrant groups: Ethnic German immigrants are granted German citizenship upon arrival, whereas immigrants studied elsewhere typically remain foreigners. This is an important difference because immigrants who possess the citizenship of the host country cannot be expelled from the country in case of conviction. This lowers the expected conviction costs which, in turn, are predicted to increase crime propensities (Becker, 1968; Spenkuch, 2013). In contrast, the immigrant groups studied in other papers face the potential risk of being deported in case of conviction.

A second potential explanation for the stronger crime impact in our study relates to the horizon over which crime effects are measured. We identify short-run effects on crime in the first two years after immigration. In contrast, other studies estimate crime impacts in the medium to long run. Recent research, however, shows that newly arriving immigrants suffer from occupational downgrading upon arrival, with labor market outcomes improving only gradually over time (e.g. Eckstein and Weiss (2004) and Dustmann et al. (2013)). Because opportunity costs of committing crimes increases with time spent in the destination country (due to having legitimate earnings opportunities), one would expect that immigrants are more criminal in the first years after arrival.

Immigrants may commit crimes themselves (direct effect) and/or immigration increases crime because residents respond to the inflow of immigrants (indirect effect). The indirect effect could arise, for example, if labor market outcomes of previous residents worsens due to the inflow of immigrants. Borjas et al. (2010), for example, show that U.S. natives, especially black males, committed more crimes in response to increased labor market competition with immigrants. This might also be one possible mechanism in our case as Glitz (2012) has shown that ethnic German immigrants displace native Germans in the labor market, with 3.1 resident workers becoming unemployed for every 10 migrants who find a job. 
Because ethnic Germans typically cannot be identified in official crime statistics due to their German nationality, we cannot directly assess whether (or how much) the increase in crime is due to a direct or indirect effect. However, a few small-scale evaluations - where the background of suspects or prison inmates has been recorded-indicate that ethnic Germans are (at least partly) directly responsible for the crime increase. Among inmates in 19 juvenile prisons in West Germany in 1998, for example, ethnic Germans are overrepresented by 100 percent relative to their population share (Pfeiffer and Dworschak, 1999). Official crime statistics of youth (under age 21) for one large state show that $18.6 \%$ of German suspects of violent crime have ethnic German background (Landeskriminalamt Baden-Württemberg, 2007). For total crime, the fraction of ethnic German suspects is $11.6 \%$. Finally, during the 1990s, when large waves of ethnic Germans immigrated, the share of ethnic Germans in juvenile prisons in Baden-Württemberg increased substantially: from $0.5 \%$ in 1993 to $19.1 \%$ in 2001 (Walter, 2002). In sum, the small-scale surveys indicate that ethnic Germans are overrepresented among suspects and prison inmates, suggesting that the increase in crime is at least partly due to a direct effect. $^{23}$

Table 3 reports crime effects for the several subcategories. For comparison, Panel A replicates the effect on total crime. Overall, immigration raises crime rates in several categories. Furthermore, almost all effects are larger than the effect on total crime. This is possible because the five subcategories cover only half of all crimes. Based on the most restrictive specification in Column (3), immigration has the largest impact on burglary (Panel B). An increase in the inflow of one immigrant per 1,000 inhabitants, increases the crime rate by $5.59 \%$ (almost six times larger than for total crime). The coefficient for property damage (Panel C) and battery (Panel D) are three times larger than the effect on total crime. The coefficient on drug offense (Panel E) is also large, but statistically insignificant. For street crime (Panel F), we find a very small (0.3\%) and statistically insignificant effect.

\subsection{Robustness Checks}

For our identification strategy to be valid, the allocation of ethnic German immigrants must not depend on regional crime rates. If regions with low crime rates, for example, would systematically receive more ethnic Germans the next year, we would underestimate the true impact of immigration on crime. To test whether this is an issue, we regress the ethnic German inflow rate in year $t$ on the crime rate in the previous year $t-1$. Following the baseline model, we condition on county and year-by-state fixed effects. Throughout various specifications with different sets of control variables, the ethnic German inflow rate in the current year is completely unrelated to the crime level in the previous year

\footnotetext{
${ }^{23}$ If the entire increase in crime was due to a direct effect, the average newly-immigrating ethnic German would raise total crime by 0.6 crimes (evaluated at the mean of 6,883 crimes per 100,000 inhabitants).
} 
(Table 4). This finding indicates that ethnic Germans have not been allocated on the basis of the crime level in a region.

Next, we show that the baseline results are robust to alternative specifications (Table 5). The baseline model is replicated in Column (1) for comparison. As a first robustness check, we weight each county-year observation with the current population size, thus giving more weight to counties with more inhabitants (Column 2). Using population weights does not change the coefficient of interest.

Crime rates within counties are persistent because of county-specific factors that change only slowly over time (e.g., criminal gangs living there). If these (unobserved) factors also influence the allocation of ethnic German immigrants, this would lead to biased estimates. To control for this potential confound directly, we add the lagged crime rate to the baseline model. Column (3) shows that controlling for the lagged crime rate does not change the results. This is consistent with the results in Table 4, which suggest that the allocation of ethnic Germans does not depend on the lagged crime rate.

Instead of controlling for the lagged crime rate and including county fixed effects, one can also exploit within-county variation in the crime rate by using a first-differenced model:

$$
\begin{aligned}
\Delta \ln {\text { crime } \text { rate }_{i s t}=} & \alpha+\beta \text { ethnic German inflow } \text { rate }_{i s t-1} \\
& +\Delta X_{i s t}^{\prime} \gamma+\left(\mu_{t} \times \mu_{s}\right)+\epsilon_{i s t}
\end{aligned}
$$

The dependent variable is the change in crime rates across two consecutive years. Control variables are also in first differences. This model is more restrictive than the model in Column (3) because the coefficient on the lagged crime rate is restricted to be equal to one. However, the first-differenced model yields a coefficient very similar to the baseline model. Standard errors, however, increase since the model explains much less of the variation in the first-differenced outcome variable (Column 4). ${ }^{24}$

Finally, we assess whether results are robust to aggregating inflows of ethnic Germans, rather than exploiting more volatile yearly inflows. First, we aggregate the inflow rates of the previous three years, that is, over the period the assignment to a particular county was binding. ${ }^{25}$ This specification mitigates idiosyncratic shocks in the lagged inflow rate. It turns out that the coefficient on the three-year ethnic German inflow rate is very similar to the baseline estimate (Column 5).

Furthermore, we aggregate inflows by using two-year averages of all variables. Specifically, we compute mean crime rates for 1997/1998, 1999/2000, 2001/2002,

\footnotetext{
${ }^{24} \mathrm{~A}$ further disadvantage of the first-differenced model is that the lagged ethnic German inflow rate is, by construction, correlated with current population and all other control variables because the covariates are based either on current or lagged population in the denominator. Therefore, the differenced control variables are to some extent bad controls since they are measured after the ethnic German inflow.

${ }^{25}$ The variable is constructed by summing the total ethnic German inflow of the previous three years $((t-1)+(t-2)+(t-3))$ and dividing the sum by population in year $t-4$. Note that using the inflows in the previous three years means that observations of the first two sample years (1997 and 1998) have to be dropped.
} 
2003/2004, and 2005/2006. Similarly, all control variables are averaged in the prior years (with the first observation starting in 1996/1997). This procedure should reduce measurement error in the relationship between the ethnic German inflow rate and the crime rate because it purges out idiosyncratic shocks of both variables. Column (6) shows that the coefficient of interest increases slightly, suggesting that measurement error might be only a minor issue. Because the number of observations is reduced by half, standard errors increase substantially, rendering the coefficient (marginally) statistically insignificant.

Another worry might be that counties with conservative political majorities are strongly opposed to receiving ethnic German immigrants. Accordingly, conservative counties might lobby the state government for reducing the number of ethnic Germans assigned to them. Since each county ultimately decides how their police resources are actually used (potentially affecting crime detection probabilities), the political majority in a county is a potential confounding factor. As we include county fixed effects in the analyses, only changes in political majorities over time are potentially problematic. We address this issue by adding several distinct measures of political majorities in our main model, e.g. by adding a dummy whether the same party has the majority in a county and the state. The results in Table A-4 indicate that the party majority in a county does not affect our baseline estimates.

One further issue might be that immigrants commit crimes in other counties than their county of residence. We use spatial lags to control for these potential regional spillovers (see Bianchi et al., 2012; Gibbons, 2004; Zenou, 2003). Spatial lags are distance-weighted averages of crime rates in neighboring regions, thus allowing for the dependence of crime rates between counties. More precisely, the spatial lag is the log of the sum of the total crime rate in all other counties, weighted by the inverse of the Euclidean geographic distance between county centroids in kilometers (distance $\mathrm{km}$ ) and the travel time distance between county capitals in car minutes (travel distance min), respectively. Each regression controls for the full set of control variables of the baseline specification. Including spatial lags does not change the results (see Table A-5). The coefficients on both versions of spatial lags are small and statistically insignificant. ${ }^{26}$ This is consistent with official statistics on criminal youth in one large German state (Baden-Württemberg), which suggest that ethnic German immigrants are more likely to commit crime in their county of residence than native Germans or foreigners (Landeskriminalamt Baden-Württemberg, 2007, p. 28). ${ }^{27}$

\footnotetext{
${ }^{26}$ Of course, we cannot use crime rates of neighboring counties that did not provide crime rates at the county level. Thus, for computing spatial lags, we are not using counties in Bavaria, Rhineland-Palatinate, Berlin or East Germany. For these regions, we have to impose the assumption that there are no spillover effects. However, we observe county-level crime rates of neighboring counties for the vast majority of counties in our sample.

${ }^{27}$ In general, crimes in Germany are committed to a large extent in the county of residence. For example, the Federal Criminal Police Office (Bundeskriminalamt) reports that about 75 percent of all crimes
} 


\subsection{Effect Heterogeneity}

So far, we have estimated at the average impact of immigration on crime across all counties. Given that the allocation of ethnic German immigrants across counties was likely homogenous with respect to individual characteristics (see Section 2), heterogeneous crime effects across regions can therefore be attributed to differences across counties (rather than to differences between ethnic German immigrants). We can therefore exploit this allocation policy to assess whether the impact of immigration on crime depends on the characteristics of the region.

We first investigate the importance of local labor market conditions. According to the economic model of crime, we expect that the effect of immigration on crime is smaller in regions with better labor market conditions because better legitimate employment opportunities increase the opportunity costs of crime.

To start with, we investigate whether the effect of immigration on crime differs between regions with different unemployment levels. To do so, we characterize counties by quartiles in the county-level unemployment rate distribution separately for each year. Counties with an unemployment rate below the $25^{t h}$ percentile in year $t-1$, for example, are indicated by $I$ (unemployment rate $_{t-1} \leq 25^{\text {th }}$ percentile).

Panel A in Table 6 indicates that counties with low levels of unemployment (below $25^{\text {th }}$ percentile) experience no crime increase with increasing immigrant inflows (Column 1). In contrast, the crime impact of immigrants in counties with high unemployment (above $75^{\text {th }}$ percentile) is $1.5 \%$ (sum of the coefficients $6.1+9.3$ ). This effect is almost twice as large as the average effect on crime $(0.9 \%)$. These results indicate that immigration does not increase crime in regions with low unemployment levels, but only increases crime in regions with higher unemployment rates.

The crime-enhancing effect of bad labor market conditions is consistent with the predictions of the economic model of crime (see Becker, 1968; Ehrlich, 1973): crime impacts are stronger in regions where legitimate earnings opportunities are scarce. The results are also in line with empirical studies showing that improvements in regional labor market conditions reduce crime rates. For example, Gould et al. (2002) and Raphael and Winter-Ebmer (2001) provide evidence for the U.S. that lower unemployment rates in local labor markets decrease the incidence of crimes, especially among less educated men. Öster and Agell (2007) find for Sweden that a decrease of municipality-level unemployment decreases crime rates. Fougère et al. (2009) provide region-level evidence for France that increases in youth unemployment increases crime.

In further analysis (available upon request), we find no evidence that crime effects differ across counties with different levels of GDP per capita. One interpretation is that GDP per capita is a poor proxy for employment opportunities. Consistent with this

reported in 2006 were committed in the county of the residence of the suspects (Bundeskriminalamt, 2006, Table 21). 
interpretation, the cross-county correlation between GDP per capita and unemployment is very low in our sample, likely because unemployment is much more volatile than GDP per capita.

To assess whether the crime impact is stronger in regions with preexisting high crime levels, we interact the immigration inflow with an indicator for whether the county has low or high crime levels. Column (1) in Panel B suggests that the crime impact of immigration is rather small in counties with low crime levels. In contrast, crime effects are strong in regions with very high crime levels (Column 3).

The stronger crime impact in regions with high crime levels is consistent with social interactions. Existing research indicates that social interactions is an important explanation for criminal behavior. Damm and Dustmann (2014), for example, find that early exposure to neighborhood crime, as measured by the share of young people convicted for crimes, increases convictions of male adolescents. Similarly, juvenile offenders who serve time in the same correctional facility affect each others criminal activities upon release (Bayer et al., 2009). Glaeser et al. (1996) provide evidence that the large cross-city variance in crime rates in the U.S. can likely not be explained by differences in costs and benefits of crime, but that social interactions have to be considerable, especially for petty and moderate crimes. Furthermore, Zenou (2003) shows that individuals are more likely to commit crimes if their peers are criminal. Given this evidence, interactions between newly arriving ethnic Germans and criminal residents might explain why crime effects are stronger in regions with higher preexisting crime levels.

Finally, we investigate whether crime effects differ across regions with different shares of foreigners. This analysis is motivated by the observation that foreigners are more likely to commit crimes than natives (Bundeskriminalamt, 2006). ${ }^{28}$ The pattern is similar to that of preexisting crime levels (Panel C): Crime effects are much larger in regions with larger shares of foreigners. Given that foreigners are on average more criminal than natives, social interactions might also drive this pattern.

\section{Conclusion}

The criminal behavior of immigrants is a huge concern among residents in many industrialized countries. Despite this fact, little is known about the impact of immigration on crime. This paper contributes to this literature, with a focus on the importance of regional labor market conditions.

We investigate the crime effect of ethnic German immigrants who were allocated across regions by German authorities upon arrival. Because this allocation was based on the presence of family members, and because noncompliance was strongly sanctioned,

\footnotetext{
${ }^{28}$ Although crime rates of natives are not directly comparable to those of foreigners (Bundeskriminalamt, 2006, p. 76), foreigners are highly overrepresented among suspects.
} 
the possibility of self-selection into regions was severely limited. Therefore, inflows into regions were likely not driven by local crime or local labor market conditions. The allocation policy thus provides a unique quasi-experimental setting for studying the effects of immigration on crime.

We find that the inflow of ethnic German immigrants strongly increased crime rates. Importantly, we find that the crime impact depends heavily on the labor market condition in a region: In regions with low unemployment, immigration does not increase crime. In contrast, in regions with high unemployment, immigration raises crime rates substantially. The crime-enhancing effect of bad labor market conditions is consistent both with the economic theory of crime and with empirical studies finding that improvements in local labor market conditions reduce crime. Furthermore, the impact of immigration on crime seems particularly strong in regions with high preexisting crime levels and in regions with large foreigner shares - findings that point toward social interactions.

Existing studies tend to find zero or small effects of immigration on crime. In contrast, this study finds large effects, suggesting that characteristics of immigrant groups are crucial for crime effects. In particular, immigrants in this study were not threatened with deportation in case of conviction. Furthermore, the findings suggest that poorly educated migrants with deficiencies in the host country language are particularly vulnerable in economically disadvantaged regions. Our study therefore cautions about comparing crime effects across countries since both labor market conditions and immigrant characteristics might differ substantially. Our results furthermore indicate that a successful integration of immigrants into the labor market immediately after arrival seems crucial for crime prevention. 


\section{References}

Acemoglu, D. and Pischke, J.-S. (2003). Minimum Wages and On-the-job Training. Research in Labor Economics, 22:159-202.

Angrist, J. D. and Pischke, J.-S. (2009). Mostly Harmless Econometrics: An Empiricist's Companion. Princeton University Press.

Bade, K. J. (1990). Aussiedler - Rückwanderer über Generationen hinweg. In Neue Heimat im Westen. Vertriebene. Flüchtlinge. Aussiedler, pages 128-149. Westfälischer Heimatbund, Münster.

Bade, K. J. and Oltmer, J. (2003). Aussiedler: deutsche Einwanderer aus Osteuropa. In Einführung: Aussiedlerzuwanderung und Aussiedlerintegration. Historische Entwicklung und aktuelle Probleme, pages 9-51. IMIS-Schriften 8, Göttingen.

Bayer, P., Hjalmarsson, R., and Pozen, D. (2009). Building Criminal Capital behind Bars: Peer Effects in Juvenile Corrections. Quarterly Journal of Economics, 124(1):105-147.

Becker, G. (1968). Crime and Punishment: An Economic Approach. Journal of Political Economy, 76(2):169-217.

Bell, B., Fasani, F., and Machin, S. (2013). Crime and Immigration: Evidence from Large Immigrant Waves. Review of Economics and Statistics, 95(4):1278-1290.

Bianchi, M., Buonanno, P., and Pinotti, P. (2012). Do Immigrants Cause Crime? Journal of the European Economic Association, 10(6):1318-1347.

Borjas, G. (1994). The Economics of Immigration. Journal of Economic Literature, 32(4):1667-1717.

Borjas, G. J. (1999). The Economic Analysis of Immigration. In Handbook of Labor Economics, volume 3A, edited by Orley C. Ashenfelter and David Card, chapter 28, pages 1697-1760. Elsevier, North-Holland, Amsterdam.

Bundeskriminalamt (2006). Polizeiliche Kriminalstatistik 2006.

Butcher, K. and Piehl, A. M. (1998). Recent Immigrants: Unexpected Implications for Crime and Incarceration. Industrial and Labor Relations Review, 51(4):654-679.

Butcher, K. and Piehl, A. M. (2007). Why are Immigrants' Incarceration Rates so Low? Evidence on Selective Immigration, Deterrence, and Deportation. NBER Working Paper No. 13229.

Camarota, S. and Vaughan, J. (2009). Immigration and Crime: Assessing a Conflicted Issue. Washington, DC: Center for Immigration Studies.

Cameron, A. C., Gelbach, J. B., and Miller, D. L. (2011). Robust Inference with Multiway Clustering. Journal of Business \& Economic Statistics, 29(2):238-249.

Card, D. (2001). Immigrant Inflows, Native Outflows, and the Local Labor Market Impacts of Higher Immigration. Journal of Labor Economics, 19(1):22-64.

Card, D. (2009). How Immigration Affects U.S. Cities. In Making Cities Work: Prospects and Policies for Urban America, edited by Robert P. Inman, chapter 6, pages 158-200. Princeton University Press, Princeton. 
Card, D., Dustmann, C., and Preston, I. (2012). Immigration, Wages, and Compositional Amenities. Journal of the European Economic Association, 10(1):78-119.

Chalfin, A. (2013). What is the Contribution of Mexican Immigration to U.S. Crime Rates? Evidence from Rainfall Shocks in Mexico. American Law and Economics Review, 16(1):220-268.

Damm, A. P. (2009). Ethnic Enclaves and Immigrant Labor Market Outcomes: QuasiExperimental Evidence. Journal of Labor Economics, 27(2):281-314.

Damm, A. P. and Dustmann, C. (2014). Does Growing Up in a High Crime Neighborhood Affect Youth Criminal Behavior? American Economic Review, 104(6):1806-1832.

Dietz, B. (1999). Jugendliche Aussiedler in Deutschland: Risiken und Chancen der Integration. In Bade, K. J. and Oltmer, J., editors, Aussiedler: Deutsche Einwanderer aus Osteuropa, pages 153-176. IMIS-Schriften 8, Göttingen.

Dustmann, C., Frattini, T., and Preston, I. (2013). The Effect of Immigration along the Distribution of Wages. Review of Economic Studies, 80(1):145-173.

Eckstein, Z. and Weiss, Y. (2004). On the Wage Growth of Immigrants: Israel, 1990-2000. Journal of the European Economic Association, 2(4):665-695.

Edin, P.-A., Fredriksson, P., and Åslund, O. (2003). Ethnic Enclaves and the Economic Success of Immigrants - Evidence from a Natural Experiment. Quarterly Journal of Economics, 118(1):329-357.

Ehrlich, I. (1973). Participation in Illegitimate Activities: A Theoretical and Empirical Investigation. Journal of Political Economy, 81(3):521-565.

Ehrlich, I. (1996). Crime, Punishment, and the Market for Offenses. Journal of Economic Perspectives, 10(1):43-67.

Fertig, M. and Schmidt, C. M. (2001). First- and Second-Generation Migrants in Germany - What Do We Know and What Do People Think. IZA Discussion Paper No. 286.

Fitzgerald, J., Curtis, K. A., and Corliss, C. L. (2012). Anxious Publics: Worries about Crime and Immigration. Comparative Political Studies, 45(4):477-506.

Fougère, D., Kramarz, F., and Pouget, J. (2009). Youth Unemployment and Crime in France. Journal of the European Economic Association, 7(5):909-938.

Freeman, R. (1999). The Economics of Crime. In Handbook of Labor Economics, volume 3C, edited by Orley C. Ashenfelter and David Card, chapter 52, pages 3529-3571. Elsevier, North-Holland, Amsterdam.

Friedberg, R. and Hunt, J. (1995). The Impact of Immigrants on Host Country Wages, Employment and Growth. Journal of Economic Perspectives, 9(2):23-44.

Gibbons, S. (2004). The Costs of Urban Property Crime. Economic Journal, 114(499):F441-F463.

Glaeser, E., Sacerdote, B., and Scheinkman, J. (1996). Crime and Social Interactions. Quarterly Journal of Economics, 111(2):507-548.

Glaeser, E. L. and Sacerdote, B. (1999). Why Is there More Crime in Cities? Journal of Political Economy, 107(S6):S225-S258. 
Glitz, A. (2012). The Labor Market Impact of Immigration: A Quasi-Experiement Exploiting Immigrant Location Rules in Germany. Journal of Labor Economics, 30(1):175-213.

Gould, E. D., Weinberg, B. A., and Mustard, D. B. (2002). Crime Rates and Local Labor Market Opportunities in the United States: 1979-1997. Review of Economics and Statistics, 84(1):45-61.

Haug, S. (2005). Zum Verlauf des Zweitspracherwerbs im Migrationskontext. Zeitschrift für Erziehungswissenschaft, 8(2):263-284.

Haug, S. and Sauer, L. (2006). Zuwanderung und räumliche Verteilung von Aussiedlern und Spätaussiedlern in Deutschland. Zeitschrift für Bevölkerungswissenschaft, 31(34):413-442.

Haug, S. and Sauer, L. (2007). Zuwanderung und Integration von (Spät-) Aussiedlern - Ermittlung und Bewertung der Auswirkungen des Wohnortzuweisungsgesetzes. Forschungsbericht 3, Bundesamt für Migration und Flüchtlinge, Nürnberg.

Hjalmarsson, R. and Lindquist, M. J. (2012). Like Godfather, Like Son: Exploring the Intergenerational Nature of Crime. Journal of Human Resources, 47(2):550-582.

Landeskriminalamt Baden-Württemberg (2007). Jugendkriminalität und Jugendgefährdung in Baden Württemberg. Jahresbericht 2006, Landeskriminalamt Baden-Württemberg, Stuttgart.

Levitt, S. (1996). The Effect of Prison Population Size on Crime Rates: Evidence from Prison Overcrowding Litigation. Quarterly Journal of Economics, 111(2):319-351.

Mammey, U. (1999). Segregation, regionale Mobilitat und soziale Integration von Aussiedlern. In Bade, K. J. and Oltmer, J., editors, Aussiedler: deutsche Einwanderer aus Osteuropa, pages 107-126. IMIS-Schriften 8, Göttingen.

Niedersächsische Landeszentrale für Politische Bildung (2002). Hier geblieben. Zuwanderung und Integration in Niedersachen 1945 bis heute. http://www.politischebildung.de/niedersachsen/hiergeblieben zuwanderung.pdf. Date Accessed: 12.07.2006.

Öster, A. and Agell, J. (2007). Crime and Unemployment in Turbulent Times. Journal of the European Economic Association, 5(4):752-775.

Peters, W. (2003). Aussiedlerzuzug: Entwicklung und Perspektiven. Zeitschrift für Ausländerrecht und Ausländerpolitik, 23(5/6):193-197.

Pfeiffer, C. and Dworschak, B. (1999). Die ethnische Vielfalt in den Jugendstrafvollzugsanstalten. Ergebnisse einer Umfrage aus dem Sommer 1998. DVJJ-Journal, $2: 184-188$.

Raphael, S. and Winter-Ebmer, R. (2001). Identifying the Effect of Unemployment on Crime. Journal of Law and Economics, 44(1):259-283.

Seifert, W. (1996). Neue Zuwanderergruppen auf dem westdeutschen Arbeitsmarkt: eine Analyse der Arbeitsmarktchancen von Aussiedlern, ausländischen Zuwanderern und ostdeutschen Übersiedlern. Soziale Welt, 2:180-201.

Spenkuch, J. L. (2013). Understanding the Impact of Immigration on Crime. American Law and Economics Review, 16(1):177-219. 
Swiaczny, F. and Mammey, U. (2001). Aussiedler. In Gans, P. and Kemper, F.-J., editors, Nationalatlas Bundesrepublik Deutschland, Band 4: Bevölkerung, pages 132135. Spektrum, Leipzig/Heidelberg.

Thompson, S. B. (2011). Simple Formulas for Standard Errors that Cluster by Both Firm and Time. Journal of Financial Economics, 99(1):1-10.

Walter, J. (2002). Jugendvollzug in der Krise? DVJJ- Journal, 5:127-143.

Wenzel, H.-J. (1999). Aussiedlerzuwanderung als Strukturproblem in ländlichen Räumen. In Bade, K. J. and Oltmer, J., editors, Aussiedler: deutsche Einwanderer aus Osteuropa, pages 265-281. IMIS-Schriften Band 8, Göttingen.

Wolfers, J. (2006). Did Unilateral Divorce Raise Divorce Rates? A Reconciliation and New Results. American Economic Review, 96(5):1802-1820.

Zenou, Y. (2003). The Spatial Aspects of Crime. Journal of the European Economic Association, 1(2-3):459-467. 


\section{Figures and Tables}

Figure 1: Annual Inflow of Ethnic German Immigrants to Germany

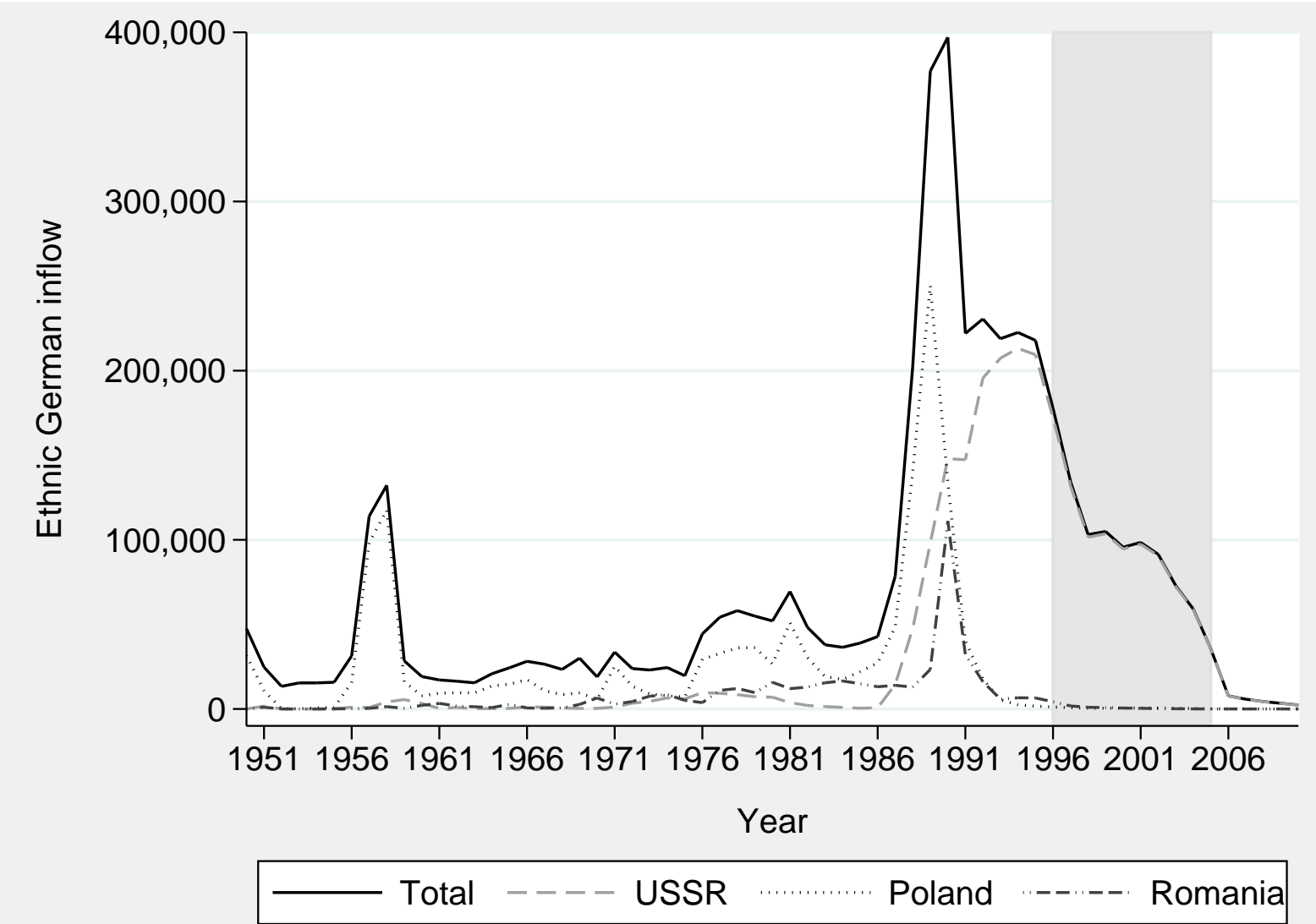

Notes: The figure shows the annual inflow of ethnic German immigrants to Germany by source country. The gray-shaded area between 1996 and 2005 highlights the period used in the analysis. Source: Federal Office of Administration (Bundesverwaltungsamt). 
Figure 2: Crime Trends by State

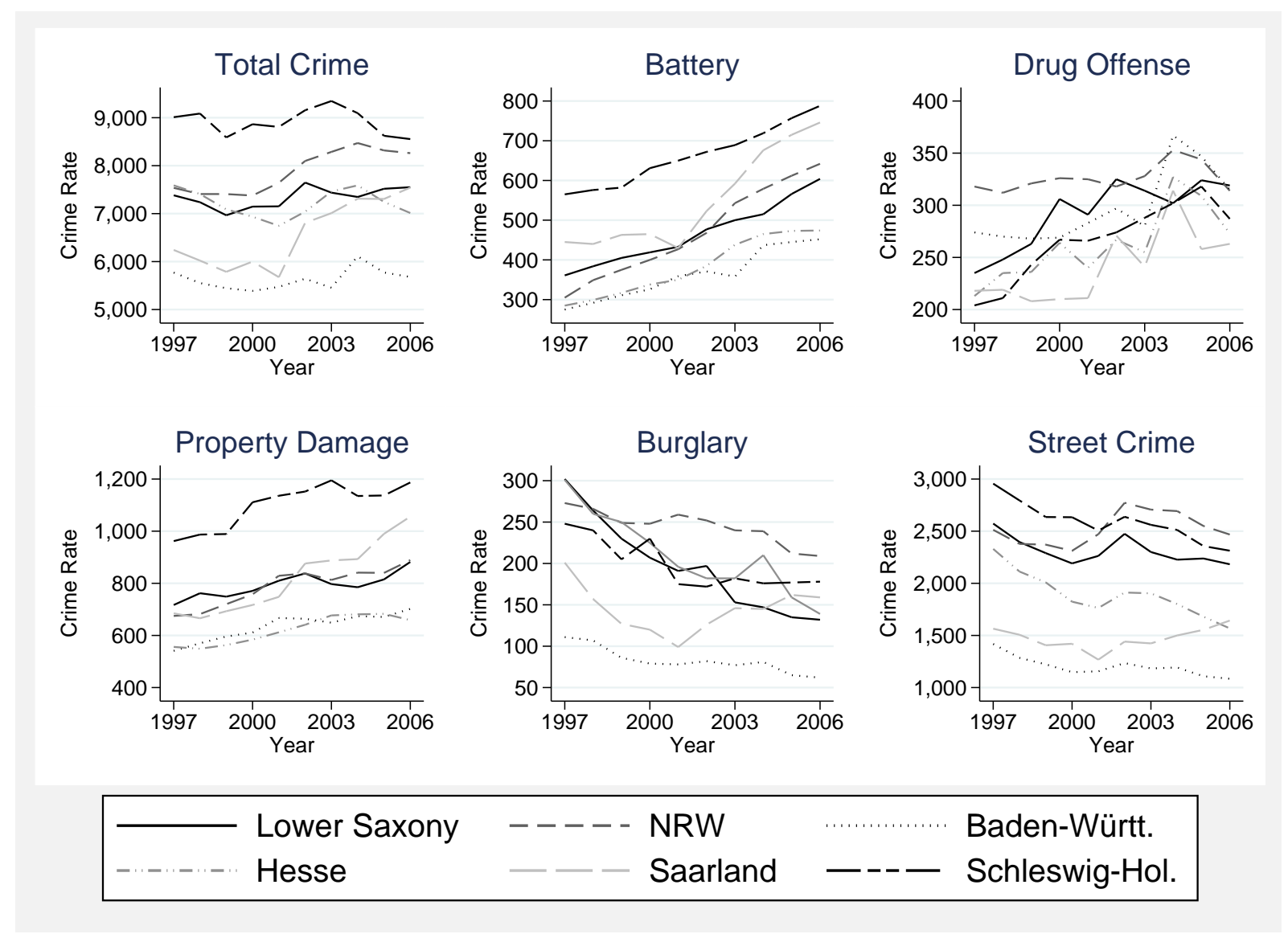

Notes: The figure shows crime rates per 100,000 residents by crime category and state. Battery includes only grievous and serious bodily harm and aggravated battery. The city states Hamburg and Bremen are excluded from the figure for expositional reasons because both states have much higher crime levels. Source: Federal Criminal Office: Police Criminal Statistics (Polizeiliche Kriminalstatistik), 1997-2006. 
Table 1: Summary Statistics

\begin{tabular}{|c|c|c|c|c|c|c|}
\hline Variable & Mean & Min & Max & $\mathrm{SD}$ & Adj. SD & Obs \\
\hline \multicolumn{7}{|c|}{ Panel A: Crime Rates } \\
\hline Total crime & 6,883 & 620 & 18,569 & 2,661 & 516 & 1,687 \\
\hline Battery & 493 & 58 & 1,727 & 222 & 46 & 1,358 \\
\hline Drug & 291 & 35 & 1,730 & 176 & 65 & 1,687 \\
\hline Property damage & 760 & 254 & 2,375 & 282 & 79 & 1,358 \\
\hline Burglary & 133 & 15 & 593 & 83 & 26 & 1,365 \\
\hline Street crime & 1,862 & 466 & 5,404 & 967 & 159 & 1,358 \\
\hline \multicolumn{7}{|c|}{ Panel B: Ethnic German Immigrants } \\
\hline Ethnic German inflow & 293 & 0 & 2,393 & 270 & 93 & 1,687 \\
\hline Ethnic German inflow rate & 0.0011 & 0 & 0.0049 & 0.0007 & 0.0004 & 1,687 \\
\hline \multicolumn{7}{|c|}{ Panel C: County Characteristics } \\
\hline Population & 262,615 & 50,878 & $1,754,182$ & 203,034 & 3,274 & 1,687 \\
\hline Foreign population share & 8.94 & 2.67 & 26.28 & 4.16 & 0.29 & 1,687 \\
\hline Young male population share & 16.76 & 13.09 & 21.41 & 1.33 & 0.17 & 1,687 \\
\hline Unemployment rate & 10.1 & 4 & 25.2 & 3.12 & 0.58 & 1,687 \\
\hline GDP per capita & 25,376 & 12,634 & 77,318 & 8,724 & 1,076 & 1,687 \\
\hline \multicolumn{7}{|c|}{ Panel D: Clear-up Rates } \\
\hline Total crime & 53.4 & 34.8 & 75.9 & 6.9 & 2.4 & 1,687 \\
\hline Battery & 90.8 & 80.4 & 99.7 & 2.9 & 1.3 & 1,358 \\
\hline Drug & 96 & 50.9 & 104.2 & 3.3 & 2.0 & 1,687 \\
\hline Property damage & 26.2 & 12.5 & 70.5 & 6 & 4.1 & 1,358 \\
\hline Burglary & 28.2 & 2 & 91.3 & 15.2 & 7.5 & 1,365 \\
\hline Street crime & 16.8 & 6.6 & 43.8 & 5 & 2.8 & 1,358 \\
\hline
\end{tabular}

Notes: Crime rates in Panel A refer to years 1997-2006. All variables in Panels B-D refer to years 1996-2005. Crime rate is defined as the number of crimes reported to the police in year $t$ per 100,000 inhabitants in year $t-1$. Ethnic German inflow rate is defined as the number of allocated ethnic German immigrants in year $t$ divided by the total population in year $t-1$. Summary statistics in Panels B-D are computed for counties with data on total crime (see Table A-3). Young male population share is the share of 15-39 year old adults in the total population. Young male population share, foreign population share, and unemployment rate are reported in percent. The adjusted standard deviation $(A d j . S D)$ is the standard deviation of the residuals obtained in a regression of the indicated variable on county and year-by-state fixed effects. Data sources: Panel A+D: State Offices of Criminal Investigation (Landeskriminalämter) for the years 1997-2002 and Federal Criminal Police Office (Bundeskriminalamt) for the years 2003-2006. Panel B: Inflow data for 1996-2001 is taken from Glitz (2012); inflow data for 2002-2006 come from the Bundesarbeitsgemeinschaft Evangelische Jugendsozialarbeit e.V., Jugendmigrationsdienste. Panel C: Population data and GDP per capita come from the Federal Statistical Office (Regionalstatistik) and unemployment rates from the Federal Employment Agency (Bundesagentur für Arbeit). 
Table 2: Effect of Ethnic German Immigrants on Total Crime

\begin{tabular}{|c|c|c|c|c|}
\hline & $(1)$ & $(2)$ & $(3)$ & $(4)$ \\
\hline & \multicolumn{4}{|c|}{ Dependent variable: log total crime rate $t_{t}$} \\
\hline Ethnic German inflow rate ${ }_{t-1}$ & $\begin{array}{c}9.303^{* *} \\
(4.591)\end{array}$ & $\begin{array}{c}9.455^{* *} \\
(4.599)\end{array}$ & $\begin{array}{c}8.756^{* *} \\
(4.196)\end{array}$ & $\begin{array}{c}7.324 \\
(6.422)\end{array}$ \\
\hline $\log _{\text {population }} t-1$ & & $\begin{array}{c}0.045 \\
(0.282)\end{array}$ & $\begin{array}{l}-0.031 \\
(0.306)\end{array}$ & $\begin{array}{l}-0.086 \\
(0.433)\end{array}$ \\
\hline Log GDP per capita $t-1$ & & $\begin{array}{c}0.016 \\
(0.061)\end{array}$ & $\begin{array}{l}-0.010 \\
(0.061)\end{array}$ & $\begin{array}{c}0.102 \\
(0.086)\end{array}$ \\
\hline Unemployment rate $_{t-1}$ & & & $\begin{array}{l}-0.006 \\
(0.005)\end{array}$ & $\begin{array}{l}-0.013 \\
(0.010)\end{array}$ \\
\hline Foreign population share $t_{-1}$ & & & $\begin{array}{c}0.003 \\
(0.004)\end{array}$ & $\begin{array}{c}0.002 \\
(0.003)\end{array}$ \\
\hline Young male population share $t_{t-1}$ & & & $\begin{array}{l}-0.021 \\
(0.020)\end{array}$ & $\begin{array}{l}-0.045 \\
(0.052)\end{array}$ \\
\hline Clear-up rate $_{t-1}$ & & & $\begin{array}{l}-0.002 \\
(0.001)\end{array}$ & $\begin{array}{c}-0.002^{*} \\
(0.001)\end{array}$ \\
\hline County fixed effects & $\mathrm{x}$ & $\mathrm{x}$ & $\mathrm{x}$ & $\mathrm{x}$ \\
\hline Year-by-state fixed effects & $\mathrm{x}$ & $\mathrm{x}$ & $\mathrm{x}$ & $\mathrm{x}$ \\
\hline County-specific linear time trends & & & & $\mathrm{x}$ \\
\hline R-squared & 0.916 & 0.916 & 0.916 & 0.928 \\
\hline Observations & 1,687 & 1,687 & 1,687 & 1,687 \\
\hline
\end{tabular}

Notes: Ethnic German inflow rate t $_{-1}$ is defined as the number of allocated ethnic German immigrants in year $t-1$ divided by the population in year $t-2$. Robust standard errors in parentheses are two-way clustered at the county and year-by-state level. Significance levels: ${ }^{* * *} \mathrm{p}<0.01,{ }^{* *} \mathrm{p}<0.05,{ }^{*} \mathrm{p}<0.1$. 


\section{Table 3: Effect of Ethnic German Immigrants on Crime Subcategories}

\begin{tabular}{lccc}
\hline \hline & $(1)$ & $(2)$ & $(3)$ \\
\hline & Panel A: log total crime rate & \\
\hline Ethnic German inflow rate $t-1$ & $9.303^{* *}$ & $9.455^{* *}$ \\
& $(4.591)$ & $(4.599)$ & $8.756^{* *}$ \\
& 0.916 & 0.916 & $(4.196)$ \\
\hline R-squared & 1,687 & 1,687 & 0.916 \\
Observations & Panel B: log burglary crime & rate & 1,687 \\
\hline \hline & $42.146^{*}$ & $53.779^{* * *}$ & $(20.477)$ \\
\hline Ethnic German inflow rate $t-1$ & $(23.259)$ & 0.898 & $(20.635)$ \\
& 0.895 & 1,365 & 0.898 \\
\hline R-squared & 1,365 & 1,365 \\
\hline \hline
\end{tabular}

\begin{tabular}{|c|c|c|c|}
\hline \multicolumn{4}{|c|}{ Panel $C:$ log property damage crime rate ${ }_{t}$} \\
\hline Ethnic German inflow rate r $_{t-1}$ & $\begin{array}{c}23.648^{* *} \\
(9.935)\end{array}$ & $\begin{array}{c}27.553^{* * *} \\
(9.755)\end{array}$ & $\begin{array}{c}27.968^{* * *} \\
(9.217)\end{array}$ \\
\hline R-squared & 0.926 & 0.926 & 0.927 \\
\hline Observations & 1,358 & 1,358 & 1,358 \\
\hline \multicolumn{4}{|c|}{ Panel D: log battery crime rate ${ }_{t}$} \\
\hline Ethnic German inflow rate $_{t-1}$ & $\begin{array}{c}20.228 \\
(13.036)\end{array}$ & $\begin{array}{c}24.656^{*} \\
(12.715)\end{array}$ & $\begin{array}{c}26.786^{* *} \\
(11.766)\end{array}$ \\
\hline R-squared & 0.945 & 0.946 & 0.946 \\
\hline Observations & 1,358 & 1,358 & 1,358 \\
\hline
\end{tabular}

Panel E: log drug offense crime rate t $_{t}$

\begin{tabular}{|c|c|c|c|}
\hline Ethnic German inflow rate ${ }_{t-1}$ & $\begin{array}{c}9.355 \\
(20.311)\end{array}$ & $\begin{array}{c}16.683 \\
(20.109)\end{array}$ & $\begin{array}{c}19.807 \\
(20.215)\end{array}$ \\
\hline R-squared & 0.831 & 0.832 & 0.833 \\
\hline Observations & 1,687 & 1,687 & 1,687 \\
\hline
\end{tabular}

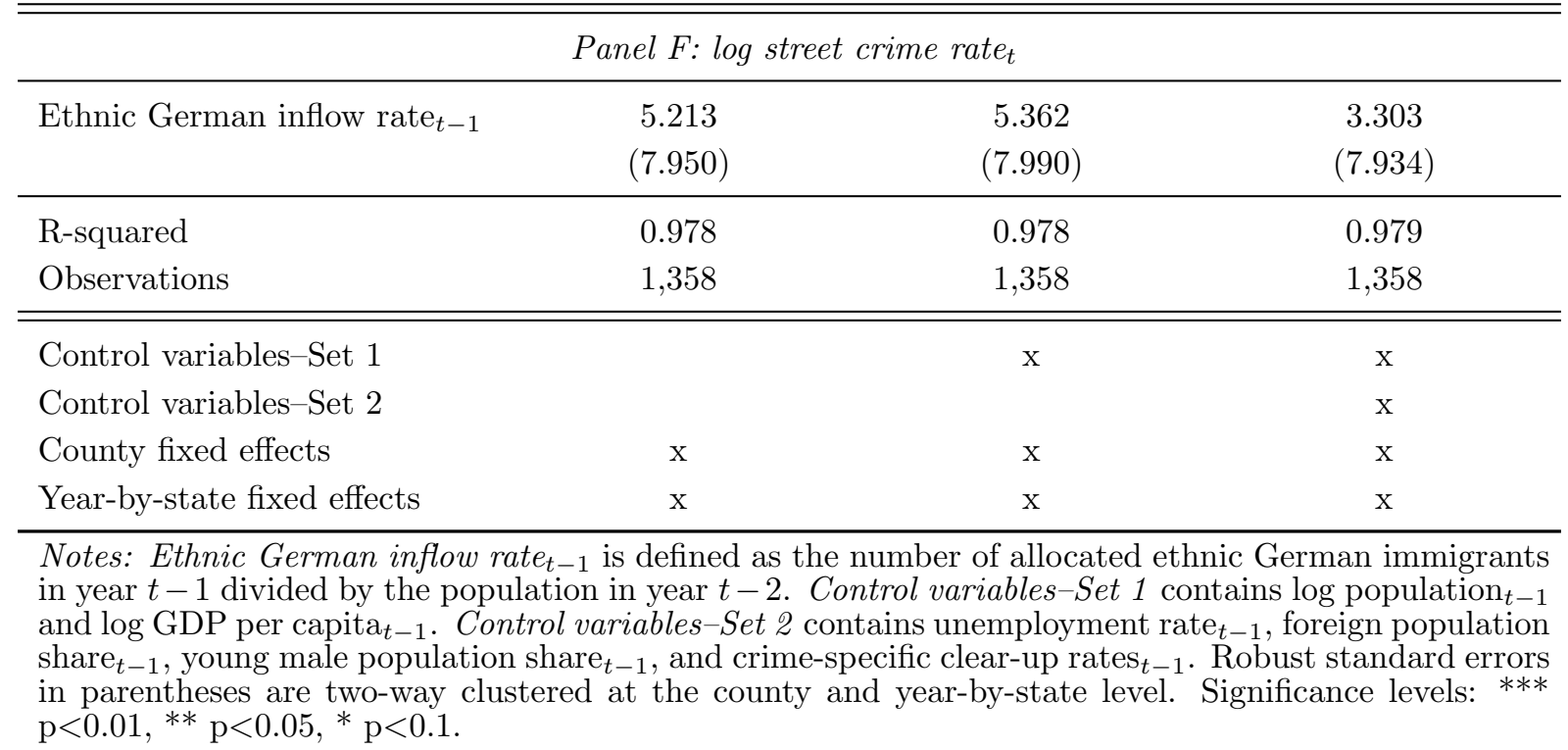


Table 4: Testing for the Effect of Lagged Crime Rates on Current Ethnic German Inflow Rates

\begin{tabular}{|c|c|c|c|c|}
\hline & (1) & $(2)$ & $(3)$ & $(4)$ \\
\hline & \multicolumn{4}{|c|}{ Dependent variable: ethnic German inflow rate $t_{t}$} \\
\hline Log total crime rate $_{t-1}$ & $\begin{array}{c}0.00005 \\
(0.00005)\end{array}$ & $\begin{array}{c}0.00006 \\
(0.00005)\end{array}$ & $\begin{array}{c}0.00005 \\
(0.00005)\end{array}$ & $\begin{array}{c}0.00006 \\
(0.00005)\end{array}$ \\
\hline $\log _{\text {population }} t-1$ & & $\begin{array}{c}-0.0048 * * * \\
(0.0017)\end{array}$ & $\begin{array}{c}-0.0045^{* * *} \\
(0.0017)\end{array}$ & $\begin{array}{c}-0.0041^{* * *} \\
(0.0015)\end{array}$ \\
\hline Log GDP per capita ch-1 $_{t}$ & & $\begin{array}{c}0.0012^{* * *} \\
(0.0004)\end{array}$ & $\begin{array}{c}0.0007 * * \\
(0.0003)\end{array}$ & $\begin{array}{c}0.0008^{* * *} \\
(0.0003)\end{array}$ \\
\hline Unemployment rate $_{t-1}$ & & & $\begin{array}{c}-0.0001^{* * *} \\
(0.00003)\end{array}$ & $\begin{array}{c}-0.0001^{* * *} \\
(0.00003)\end{array}$ \\
\hline Foreign population share ${ }_{t-1} \times 10^{-3}$ & & & $\begin{array}{c}0.0004 \\
(0.0108)\end{array}$ & $\begin{array}{l}-0.0005 \\
(0.0099)\end{array}$ \\
\hline $\begin{array}{l}\text { Ethnic German inflow rate } \\
\text { of previous } 3 \text { years }_{t-1}\end{array}$ & & & & $\begin{array}{c}0.0177 \\
(0.0265)\end{array}$ \\
\hline County fixed effects & $\mathrm{x}$ & $\mathrm{x}$ & $\mathrm{x}$ & $\mathrm{x}$ \\
\hline Year-by-state fixed effects & $\mathrm{x}$ & $\mathrm{x}$ & $\mathrm{x}$ & $\mathrm{x}$ \\
\hline R-squared & 0.708 & 0.721 & 0.727 & 0.729 \\
\hline Observations & 1,660 & 1,660 & 1,660 & 1,660 \\
\hline
\end{tabular}

Notes: Ethnic German inflow rate of previous 3 years $_{t-1}=$ ethnic German inflow rate $t_{t-1}+$ ethnic German inflow rate $t_{t-2}+$ ethnic German inflow rate $t-3$. Robust standard errors in parentheses are two-way clustered at the county and year-by-state level. Significance levels: $* * * \mathrm{p}<0.01,{ }^{* *} \mathrm{p}<0.05,{ }^{*}$ $\mathrm{p}<0.1$. 
Table 5: Alternative Model Specifications

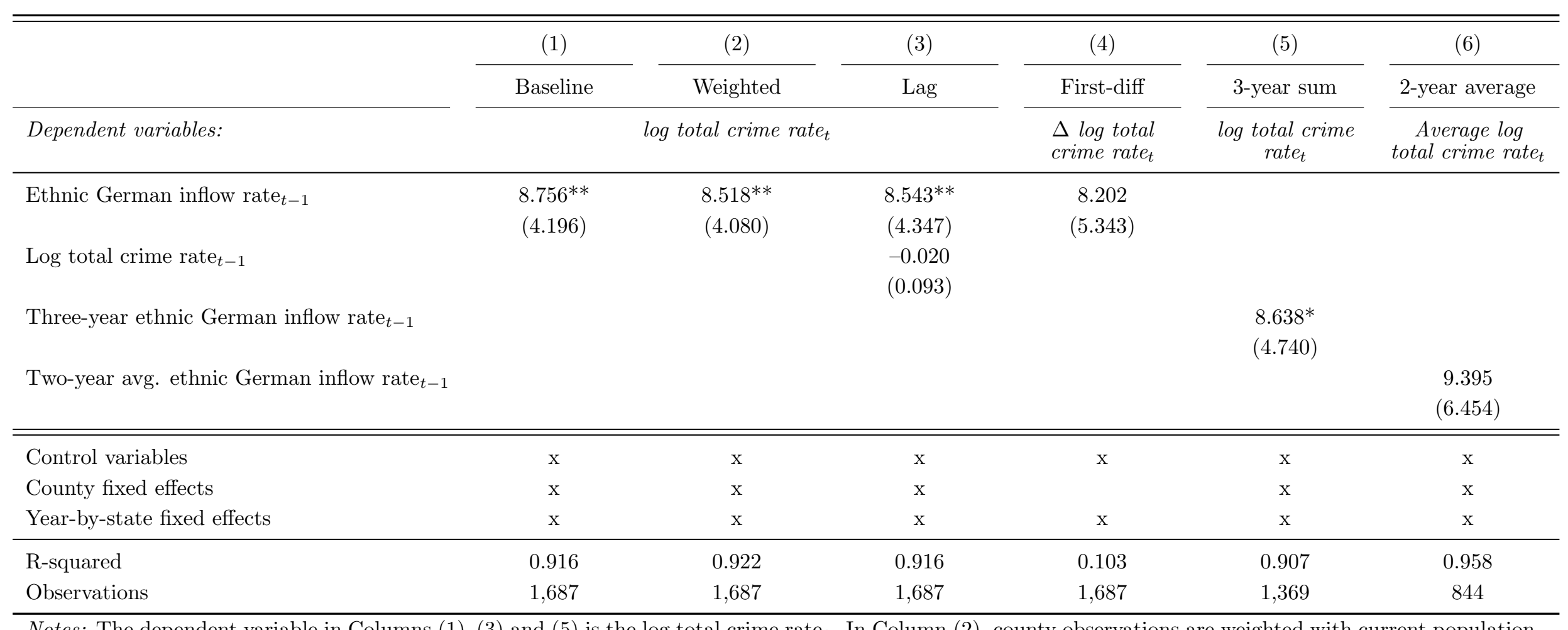

Notes: The dependent variable in Columns (1)-(3) and (5) is the log total crime rate $t_{t}$ In Column (2), county observations are weighted with current population. In Column (4), the dependent variable is in first differences: $\Delta$ log total crime rate r $_{t}=\log$ total crime rate - log total crime rate $_{t-1}$. All control variables are also in first differences. In Column (6), crime rates are averaged over two consecutive years $(1997 / 1998,1999 / 2000,2001 / 2002,2003 / 2004$, and 2005/2006). Similarly, all control variables are averaged in the prior years (with the first observation starting in 1996/1997). Ethnic German inflow rate $t_{-1}$ is defined as the number of allocated ethnic German immigrants in year $t-1$ divided by the population in year $t-2$. Three-year ethnic German inflow rate $t-1$ equals ethnic German inflow in year $(t-1)+(t-2)+(t-3)$ over population in year $t-4$. Two-year average ethnic German inflow rate $t_{t-1}$ equals the simple average of the ethnic German inflow rate of two consecutive years, starting with the first observation in 1996/1997. Control variables include log population $t-1$, log GDP per capita $_{t-1}$, unemployment rate $t_{-1}$, foreign population share $t-1$, young male population share $t_{-1}$, and clear-up rate $t_{-1}$. Robust standard errors in parentheses are two-way clustered at the county and year-by-state level. Significance levels: ${ }^{* * *} \mathrm{p}<0.01,{ }^{* *} \mathrm{p}<0.05,{ }^{*} \mathrm{p}<0.1$ 
Table 6: Effect Heterogeneity

\begin{tabular}{|c|c|c|c|}
\hline & $(1)$ & $(2)$ & $(3)$ \\
\hline & \multicolumn{3}{|c|}{ Dependent variable: log total crime rate ${ }_{t}$} \\
\hline \multicolumn{4}{|c|}{ Panel A: Interaction with Unemployment Level } \\
\hline Ethnic German inflow rate $_{t-1}$ & $\begin{array}{c}11.369^{* *} \\
(4.479)\end{array}$ & $\begin{array}{c}3.529 \\
(5.838)\end{array}$ & $\begin{array}{c}6.110 \\
(4.911)\end{array}$ \\
\hline Inflow rate $\times \mathrm{I}\left(\right.$ unemployment rate $_{t-1} \leq 25^{t h}$ percentile $)$ & $\begin{array}{c}-12.393^{*} \\
(6.370)\end{array}$ & & \\
\hline Inflow rate $\times I\left(\right.$ unemployment rate $_{t-1} \geq 50^{t h}$ percentile $)$ & & $\begin{array}{l}9.243^{*} \\
(5.119)\end{array}$ & \\
\hline Inflow rate $\times I\left(\right.$ unemployment rate $_{t-1} \geq 75^{t h}$ percentile $)$ & & & $\begin{array}{c}9.303 \\
(7.056)\end{array}$ \\
\hline Effect for counties in indicator function & $\begin{array}{l}-1.024 \\
(7.109)\end{array}$ & $\begin{array}{c}12.772^{* * *} \\
(4.573)\end{array}$ & $\begin{array}{c}15.413^{* *} \\
(6.515)\end{array}$ \\
\hline \multicolumn{4}{|c|}{ Panel B: Interaction with Preexisting Crime Level } \\
\hline Ethnic German inflow rate r $_{t-1}$ & $\begin{array}{c}9.868^{* *} \\
(4.346)\end{array}$ & $\begin{array}{c}7.238 \\
(5.003)\end{array}$ & $\begin{array}{c}6.513 \\
(4.432)\end{array}$ \\
\hline Inflow rate $\times I\left(\log\right.$ total crime rate $_{t-1} \leq 25^{t h}$ percentile $)$ & $\begin{array}{l}-4.637 \\
(8.896)\end{array}$ & & \\
\hline Inflow rate $\times I\left(\log\right.$ total crime rate $_{t-1} \geq 50^{t h}$ percentile $)$ & & $\begin{array}{c}3.392 \\
(4.824)\end{array}$ & \\
\hline Inflow rate $\times I\left(\log\right.$ total crime rate $_{t-1} \geq 75^{t h}$ percentile $)$ & & & $\begin{array}{c}16.410^{* *} \\
(8.076)\end{array}$ \\
\hline Effect for counties in indicator function & $\begin{array}{c}5.231 \\
(8.604)\end{array}$ & $\begin{array}{c}10.629^{* *} \\
(4.742)\end{array}$ & $\begin{array}{c}22.922^{* * *} \\
(8.136)\end{array}$ \\
\hline \multicolumn{4}{|c|}{ Panel C: Interaction with Share of Foreigners } \\
\hline Ethnic German inflow rate ${ }_{t-1}$ & $\begin{array}{c}10.854^{* *} \\
(4.491)\end{array}$ & $\begin{array}{l}9.502^{*} \\
(4.914)\end{array}$ & $\begin{array}{l}7.504^{*} \\
(4.227)\end{array}$ \\
\hline Inflow rate $\times \mathrm{I}\left(\right.$ foreigner share ${ }_{t-1} \leq 25^{t h}$ percentile $)$ & $\begin{array}{c}-7.256 \\
(10.286)\end{array}$ & & \\
\hline Inflow rate $\times I\left(\right.$ foreigner share $t-1 \geq 50^{t h}$ percentile $)$ & & $\begin{array}{l}-2.491 \\
(8.998)\end{array}$ & \\
\hline Inflow rate $\times I\left(\right.$ foreigner share $t-1 \geq 75^{t h}$ percentile $)$ & & & $\begin{array}{l}14.033 \\
(12.152)\end{array}$ \\
\hline Effect for counties in indicator function & $\begin{array}{c}3.598 \\
(9.236)\end{array}$ & $\begin{array}{c}7.010 \\
(7.692)\end{array}$ & $\begin{array}{l}21.537^{*} \\
(12.163)\end{array}$ \\
\hline Control variables & $\mathrm{x}$ & $\mathrm{x}$ & $\mathrm{x}$ \\
\hline County fixed effects & $\mathrm{x}$ & $\mathrm{x}$ & $\mathrm{x}$ \\
\hline Year-by-state fixed effects & $\mathrm{x}$ & $\mathrm{x}$ & $\mathrm{x}$ \\
\hline
\end{tabular}

Notes: Ethnic German inflow rate t-1 $_{1}$ is defined as the number of allocated ethnic German immigrants in year $t-1$ divided by the population in year $t-2$. Inflow rate denotes ethnic German inflow rate in-1 $_{\text {. }}$. $I(\cdot)$ denotes an indicator variable. Control variables: log GDP per capita $t_{-1}$, unemployment rate $_{t-1}$, log population $t_{t-1}$, foreign population share $t_{-1}$, young male population share s $_{t-1}$, and clear-up rate ret $_{t-1}$. R-squared $(=0.916)$ and number of observations $(1,687)$ are the same in each model. Robust standard errors in parentheses are two-way clustered at the county and year-by-state level. Significance levels: $* * * \mathrm{p}<0.01, * * \mathrm{p}<0.05, * \mathrm{p}<0.1$. 
Table A-1: Determinants of Ethnic German Immigrant Inflow into Counties

\begin{tabular}{|c|c|c|c|c|c|c|c|}
\hline & (1) & $(2)$ & $(3)$ & $(4)$ & $(5)$ & $(6)$ & (7) \\
\hline & \multicolumn{7}{|c|}{ Dependent variable: ethnic German inflow } \\
\hline Log population $_{t-1}$ & $\begin{array}{c}306.33^{* * *} \\
(32.54)\end{array}$ & & & & $\begin{array}{c}329.12^{* * *} \\
(35.29)\end{array}$ & & $\begin{array}{c}112.61^{* * *} \\
(28.95)\end{array}$ \\
\hline Log GDP per capita ch-1 & & $\begin{array}{l}102.81 \\
(69.47)\end{array}$ & & & $\begin{array}{c}57.99 \\
(43.47)\end{array}$ & & $\begin{array}{c}11.38 \\
(18.06)\end{array}$ \\
\hline 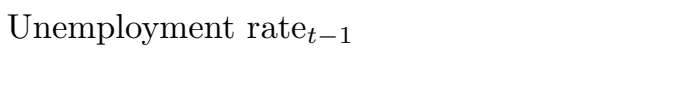 & & & $\begin{array}{l}-6.28 \\
(6.51)\end{array}$ & & $\begin{array}{c}0.64 \\
(3.42)\end{array}$ & & $\begin{array}{c}0.36 \\
(1.60)\end{array}$ \\
\hline Foreign population share ${ }_{t-1}$ & & & & $\begin{array}{c}13.03^{* *} \\
(5.18)\end{array}$ & $\begin{array}{c}-9.47^{* * *} \\
(3.31)\end{array}$ & & $\begin{array}{l}-1.57 \\
(1.33)\end{array}$ \\
\hline Ethnic German inflow of previous 3 years $_{t-1}$ & & & & & & $\begin{array}{c}0.22^{* * *} \\
(0.01)\end{array}$ & $\begin{array}{c}0.17^{* * *} \\
(0.02)\end{array}$ \\
\hline Year fixed effects & $\mathrm{x}$ & $\mathrm{x}$ & $\mathrm{x}$ & $\mathrm{x}$ & $\mathrm{x}$ & $\mathrm{x}$ & $\mathrm{x}$ \\
\hline R-squared & 0.618 & 0.147 & 0.140 & 0.177 & 0.630 & 0.767 & 0.795 \\
\hline Observations & 1,660 & 1,660 & 1,660 & 1,660 & 1,660 & 1,660 & 1,660 \\
\hline
\end{tabular}

Notes: Ethnic German inflow is the number of ethnic German immigrants allocated to a given county in year $t$. Robust standard errors in parentheses are two-way clustered at the county and year-by-state level. Significance levels: ${ }^{* * *} \mathrm{p}<0.01,{ }^{* *} \mathrm{p}<0.05,{ }^{*} \mathrm{p}<0.1$. 


\section{Table A-2: Characteristics of Ethnic German Immigrants, Other Immigrants, and Native Germans}

\begin{tabular}{|c|c|c|c|c|c|}
\hline \multirow[b]{2}{*}{ Variable } & \multirow[b]{2}{*}{$\begin{array}{l}\text { Ethnic } \\
\text { Germans }\end{array}$} & \multirow[b]{2}{*}{$\begin{array}{c}\text { Other } \\
\text { Immigrants }\end{array}$} & \multirow[b]{2}{*}{$\begin{array}{l}\text { Native } \\
\text { Germans }\end{array}$} & \multicolumn{2}{|c|}{ Ethnic Germans - } \\
\hline & & & & $\begin{array}{c}\text { Other } \\
\text { Immigrants }\end{array}$ & $\begin{array}{l}\text { Native } \\
\text { Germans }\end{array}$ \\
\hline \multicolumn{6}{|c|}{ Panel A: Demographics } \\
\hline Age & $\begin{array}{c}35.0 \\
(22.3)\end{array}$ & $\begin{array}{c}33.1 \\
(17.5)\end{array}$ & $\begin{array}{c}44.8 \\
(11.3)\end{array}$ & $\begin{array}{l}1.9^{* * *} \\
{[0.352]}\end{array}$ & $\begin{array}{c}-9.81^{* * *} \\
{[0.177]}\end{array}$ \\
\hline Male & 0.49 & 0.46 & 0.49 & $\begin{array}{c}0.03 * * * \\
{[0.008]}\end{array}$ & $\begin{array}{c}0.00 \\
{[0.001]}\end{array}$ \\
\hline Years since migration & $\begin{array}{c}8.5 \\
(4.6)\end{array}$ & $\begin{array}{c}7.4 \\
(3.9)\end{array}$ & $\mathrm{n} / \mathrm{a}$ & $\begin{array}{l}1.1^{* * *} \\
{[0.076]}\end{array}$ & $\mathrm{n} / \mathrm{a}$ \\
\hline German citizenship & 1 & 0.143 & 1 & $\begin{array}{c}0.857^{* * *} * \\
{[0.0002]}\end{array}$ & 0 \\
\hline \multicolumn{6}{|c|}{ Panel B: Education } \\
\hline ISCED 1 & 0.107 & 0.176 & 0.017 & $\begin{array}{c}-0.069 * * * \\
{[0.009]}\end{array}$ & $\begin{array}{c}0.087^{* * *} \\
{[0.003]}\end{array}$ \\
\hline ISCED 2 & 0.298 & 0.250 & 0.172 & $\begin{array}{c}0.048^{* * *} * \\
{[0.01]}\end{array}$ & $\begin{array}{c}0.126^{* * *} \\
{[0.006]}\end{array}$ \\
\hline ISCED 3 & 0.439 & 0.291 & 0.528 & $\begin{array}{c}0.148^{* * *} * \\
{[0.011]}\end{array}$ & $\begin{array}{c}-0.089 * * * \\
{[0.009]}\end{array}$ \\
\hline ISCED 4-6 & 0.156 & 0.283 & 0.284 & $\begin{array}{c}-0.127^{* * *} \\
{[0.013]}\end{array}$ & $\begin{array}{c}-0.128^{* * *} \\
{[0.010]}\end{array}$ \\
\hline \multicolumn{6}{|c|}{ Panel C: Employment } \\
\hline Unemployment rate & 0.127 & 0.141 & 0.047 & $\begin{array}{l}-0.014 \\
{[0.016]}\end{array}$ & $\begin{array}{c}0.080^{* * *} \\
{[0.007]}\end{array}$ \\
\hline Employment ratio & 0.820 & 0.779 & 0.887 & $\begin{array}{l}0.041^{* *} \\
{[0.017]}\end{array}$ & $\begin{array}{c}-0.067 * * * \\
{[0.009]}\end{array}$ \\
\hline Full-time working & 0.933 & 0.844 & 0.951 & $\begin{array}{c}0.089^{* * *} * \\
{[0.014]}\end{array}$ & $\begin{array}{c}-0.018^{* * *} * \\
{[0.006]}\end{array}$ \\
\hline Usual hours worked & $\begin{array}{l}40.7 \\
(7.5)\end{array}$ & $\begin{array}{c}42.1 \\
(11.6)\end{array}$ & $\begin{array}{c}42.8 \\
(11.5)\end{array}$ & $\begin{array}{c}-1.4^{* * *} \\
{[0.274]}\end{array}$ & $\begin{array}{l}-2.1^{* * * *} \\
{[0.247]}\end{array}$ \\
\hline Temporary & 0.165 & 0.171 & 0.059 & $\begin{array}{l}-0.006 \\
{[0.016]}\end{array}$ & $\begin{array}{c}0.106^{* * *} \\
{[0.008]}\end{array}$ \\
\hline \multicolumn{6}{|c|}{ Panel D: Net income } \\
\hline$<900$ & 0.125 & 0.185 & 0.054 & $\begin{array}{c}-0.060^{* * *} \\
{[0.018]}\end{array}$ & $\begin{array}{c}0.071^{* * *} \\
{[0.002]}\end{array}$ \\
\hline $900-1,500$ & 0.428 & 0.373 & 0.222 & $\begin{array}{c}0.055^{* * * *} \\
{[0.019]}\end{array}$ & $\begin{array}{c}0.206^{* * *} \\
{[0.013]}\end{array}$ \\
\hline $1,500-2,000$ & 0.286 & 0.232 & 0.257 & $\begin{array}{c}0.054^{* * *} * \\
{[0.015]}\end{array}$ & $\begin{array}{c}0.029^{* *} \\
{[0.011]}\end{array}$ \\
\hline $2,000-2,600$ & 0.122 & 0.121 & 0.216 & $\begin{array}{c}0.001 \\
{[0.013]}\end{array}$ & $\begin{array}{c}-0.094^{* * *} * \\
{[0.01]}\end{array}$ \\
\hline $2,600-4,000$ & 0.031 & 0.060 & 0.175 & $\begin{array}{c}-0.029^{* * * *} \\
{[0.009]}\end{array}$ & $\begin{array}{c}-0.144^{* * *} \\
{[0.01]}\end{array}$ \\
\hline$>4,000$ & 0.007 & 0.029 & 0.077 & $\begin{array}{c}-0.022^{* * *} \\
{[0.005]}\end{array}$ & $\begin{array}{c}-0.070 * * * \\
{[0.006]}\end{array}$ \\
\hline \multicolumn{6}{|c|}{ Panel E: Social Assistance } \\
\hline Hartz IV & 0.178 & 0.194 & 0.051 & $\begin{array}{l}-0.016 \\
{[0.018]}\end{array}$ & $\begin{array}{c}0.127^{* * *} \\
{[0.007]}\end{array}$ \\
\hline ALG I & 0.035 & 0.042 & 0.016 & $\begin{array}{l}-0.007 \\
{[0.007]}\end{array}$ & $\begin{array}{c}0.019^{* * *} \\
{[0.003]}\end{array}$ \\
\hline
\end{tabular}

Notes: The samples of ethnic Germans and other immigrants include only individuals who immigrated to Germany between 1996 and 2005. Samples are restricted to the eight German states included in the analysis. Samples in Panel A contain 4,292 ethnic Germans, 9,469 other immigrants, and 320,328 native Germans, respectively. The number of observations are lower in the other panels, depending on the sample restrictions used. Statistics are weighted by population weights. The sample in Panel B is restricted to persons not in school. Samples in Panel C are restricted either to males of working age, that is, 25 to 60 years old, not in school, and either employed or unemployed. Employment ratio gives the share of employed over the male working age population. For full-time and temporary working, the sample is restricted to employed persons only. Usual hours worked includes only full-time employed males. The sample in Panel D is restricted to employed males of working age who are not in school. Net income is the net income in the previous month in current (2008) Euro. Samples in Panel E include males of working age who are not in school. Hartz $I V$ refers to public social assistance for medium- and long-term unemployed and $A L G I$ refers to public social assistance for short-term unemployed $(<1$ year). Standard deviations in parentheses and standard errors in brackets. Significance levels: ${ }^{* * *} \mathrm{p}<0.01,{ }^{* *} \mathrm{p}<0.05,{ }^{*} \mathrm{p}<0.1$.

Data source: Special evaluation of the German Microcensus 2008 by the German Federal Statistical Office. 
Table A-3: Analysis Sample

\begin{tabular}{lcccccccc}
\hline \hline State & Counties & Years & \multicolumn{7}{c}{ County-year observations by crime category } \\
\hline & & & $(1)$ & $(2)$ & $(3)$ & $(4)$ & $(5)$ & $(6)$ \\
\hline Baden-Württemberg $^{*}$ & 44 & $1997-2006$ & 440 & 440 & 440 & 440 & 440 & 440 \\
Bremen $^{a}$ & 1 & $1997-2006$ & 10 & 3 & 10 & 3 & 10 & 3 \\
Hamburg $^{b}$ & 1 & $1999-2006$ & 7 & 7 & 7 & 7 & 7 & 7 \\
Hesse $^{c}$ & 26 & $2003-2006$ & 104 & 104 & 104 & 104 & 104 & 104 \\
Lower Saxony $^{d}$ & 46 & $1997-2006$ & 456 & 456 & 456 & 456 & 456 & 456 \\
North Rhine-Westphalia $^{e}$ & 46 & $1997-2006$ & 460 & 138 & 460 & 138 & 138 & 138 \\
Saarland $_{\text {Schleswig-Holstein }}^{6}$ & $1997-2006$ & 60 & 60 & 60 & 60 & 60 & 60 \\
& 15 & $1997-2006$ & 150 & 150 & 150 & 150 & 150 & 150 \\
\hline Total & 185 & & 1,687 & 1,358 & 1,687 & 1,358 & 1,365 & 1,358 \\
\hline
\end{tabular}

Notes: Crime categories: (1) total crime, (2) battery, (3) drug, (4) property damage, (5) burglary, and (6) street crime. ${ }^{a}$ Bremen consists of two counties, but crime data are available only at the state level. Crime rates for (2), (4), and (6) are available only for years 2003-2006. ${ }^{b}$ Crime data are available only for years 1999-2006. ${ }^{c}$ Allocation of ethnic Germans started only in 2002. ${ }^{d}$ Ethnic German inflow data not available for city of Hannover for 2003-2006. ${ }^{e}$ Crime rates for (2), (4), (5), and (6) are available only for years 2003-2006. 


\section{Table A-4: Effect of Ethnic German Immigrants on Total Crime Controlling for Political Majority}

\begin{tabular}{|c|c|c|c|c|}
\hline & $(1)$ & $(2)$ & $(3)$ & $(4)$ \\
\hline & \multicolumn{4}{|c|}{ Dependent variable: log total crime rate $t_{t}$} \\
\hline Ethnic German inflow rate ${ }_{t-1}$ & $\begin{array}{c}8.756^{* *} \\
(4.196)\end{array}$ & $\begin{array}{c}8.850^{* *} \\
(4.269)\end{array}$ & $\begin{array}{c}8.661^{* *} \\
(4.281)\end{array}$ & $\begin{array}{c}8.969 * * \\
(4.177)\end{array}$ \\
\hline Social Democrats simple majority $t-1$ & & $\begin{array}{l}-0.014 \\
(0.012)\end{array}$ & $\begin{array}{l}-0.015 \\
(0.012)\end{array}$ & \\
\hline Different simple majority in state and county $t_{t-1}$ & & & $\begin{array}{c}0.008 \\
(0.010)\end{array}$ & \\
\hline Conservatives/Liberals absolute majority $t-1$ & & & & $\begin{array}{c}0.004 \\
(0.013)\end{array}$ \\
\hline Social Democrats/Greens absolute majority ${ }_{t-1}$ & & & & $\begin{array}{l}-0.016 \\
(0.020)\end{array}$ \\
\hline Control variables & $\mathrm{x}$ & $\mathrm{x}$ & $\mathrm{x}$ & $\mathrm{x}$ \\
\hline County fixed effects & $\mathrm{x}$ & $\mathrm{x}$ & $\mathrm{x}$ & $\mathrm{x}$ \\
\hline Year-by-state fixed effects & $\mathrm{x}$ & $\mathrm{x}$ & $\mathrm{x}$ & $\mathrm{x}$ \\
\hline R-squared & 0.916 & 0.916 & 0.916 & 0.916 \\
\hline Observations & 1,687 & 1,687 & 1,687 & 1,687 \\
\hline
\end{tabular}

Notes: Ethnic German inflow rate t-1 $_{1}$ is defined as the number of allocated ethnic German immigrants in year $t-1$ divided by the population in year $t-2$. Control variables: log population ${ }_{t-1}, \log$ GDP per capita $t_{-1}$, unemployment rate $_{t-1}$, foreign population share $t_{-1}$, young male population share t-1 $_{t}$, and clear-up rate $t_{t-1}$. Social Democrats simple majority . $_{t-1}$ equals 1 if the Social Democratic Party (SPD) has the largest share of votes; 0 otherwise. Conservatives/Liberals absolute majority $y_{-1}$ equals 1 if the conservative party, the Christian Democratic Union (CDU), and the liberal party, the Free Democratic Party (FDP), together have the majority of votes; 0 otherwise. Social Democrats/Greens absolute majority $t_{t-1}$ equals 1 if the Social Democratic Party (SPD) and the Green party together have the majority of votes; 0 otherwise. Different majority in state and county $t_{-1}$ equals 1 if the party with the largest share of votes in the county is different than the party with the largest share of votes in the state; 0 otherwise. Robust standard errors in parentheses are two-way clustered at the county and year-by-state level. Data on party votes come from the Federal Statistical Office and the State Statistical Offices (Regionalstatistik). Shares of votes refer to second votes in the regional elections and in the state elections, respectively. Significance levels: $* * * \mathrm{p}<0.01,{ }^{*} \mathrm{p}<0.05,{ }^{*} \mathrm{p}<0.1$. 


\section{Table A-5: Effect of Ethnic German Immigrants on Total Crime Including Spatially Lagged Crime Rates}

\begin{tabular}{|c|c|c|c|}
\hline & $(1)$ & $(2)$ & $(3)$ \\
\hline & \multicolumn{3}{|c|}{ Dependent variable: log total crime rate $t_{t}$} \\
\hline Ethnic German inflow rate ${ }_{t-1}$ & $\begin{array}{c}8.756^{* *} \\
(4.196)\end{array}$ & $\begin{array}{c}9.269 * * \\
(4.709)\end{array}$ & $\begin{array}{c}10.584^{* *} \\
(5.266)\end{array}$ \\
\hline Spatial lag (distance in kilometers) & & $\begin{array}{l}-0.381 \\
(0.813)\end{array}$ & \\
\hline Spatial lag (travel distance in minutes) & & & $\begin{array}{l}-2.417 \\
(1.665)\end{array}$ \\
\hline Control variables & $\mathrm{x}$ & $\mathrm{x}$ & $\mathrm{x}$ \\
\hline County fixed effects & $\mathrm{x}$ & $\mathrm{x}$ & $\mathrm{x}$ \\
\hline Year-by-state fixed effects & $\mathrm{x}$ & $\mathrm{x}$ & $\mathrm{x}$ \\
\hline R-squared & 0.916 & 0.916 & 0.917 \\
\hline Observations & 1,687 & 1,687 & 1,687 \\
\hline
\end{tabular}

Notes: The spatial lag is the log of the sum of the total crime rate in all other counties, weighted by the inverse of the Euclidean geographic distance between county centroids in kilometers or the travel time distance between county capitals in car minutes. Control variables: log population $t_{-1}$, log GDP per capita $t_{t-1}$, unemployment rate $_{t-1}$, foreign population share $t_{-1}$, young male population share s-1 $_{t-1}$, and clear-up rate for total crime $t_{-1}$. Ethnic German inflow rate $t_{t-1}$ equals the ethnic German inflow in year $t-1$ over population in year $t-2$. Robust standard errors in parentheses are two-way clustered at the county and year-by-state level. Significance levels: ${ }^{* * *} \mathrm{p}<0.01,{ }^{* *} \mathrm{p}<0.05,{ }^{*} \mathrm{p}<0.1$. 